\title{
YASAMA DOKUNULMAZLIĞI Bir Karşılaştırmalı Anayasa Hukuku Incelemesi
}

\author{
Doç. Dr. Kemal Gözler \\ Uludag Üniversitesi \\ Iktisadî ve Idarî Bilimler Fakültesi
}

\section{Özet}

Bu makalede, yirmi beş ülkenin anayasal düzenlemelerinden hareketle, yasama dokunulmazlığı kurumu karşlaştırmalı olarak incelenmektedir. Yasama dokunulmazlığı parlâmento üyelerine gözaltına alınmamama, tutuklanmama kovuşturulmama gibi güvenceler sağlamaktadır. Incelediğimiz ülkelerin sadece ikisinde (Hollanda ve Yeni Zelanda) yasama dokunulmazlı̆̆ kurumu mevcut değildir. Íncelediğimiz ülkelerin beşinde (ABD, Avustralya, Ingiltere, Irlanda ve Kanada) yasama dokunulmazlı̆̆ sadece hukukî alanda, on dördünde (Almanya, Avusturya, Belçika, Finlandiya, Fransa, Ispanya, Isveç, Isviçre, Italya, Izlanda, Japonya, Portekiz, Türkiye ve Yunanistan) sadece cezaî alanda ve dördünde (Danimarka, İsrail, Lüksemburg ve Norvę) hem cezaî, hem de hukukî alanda geçerlidir. Yasama dokunulmazlığın cezaî alanda tanıyan ülkelerin hepsinde bu dokunulmazlık parlâmento tarafından kaldırlabilir. Ancak suçüstü hâli gibi bazı durumlarda yasama dokunulmazlı̆̆ı kaldırılmasına gerek yoktur.

\section{The Parliamentary Inviolability: A Comparative Constitutional Law Study}

\section{Abstract}

This article examines the parliamentary inviolability from a comparative point of view on the basis of the constitutional stipulations of twenty-five countries. Parliamentary inviolability protects the members of parliament from arrest, from being held in preventive custody and from the opening of judicial proceedings against them. Among countries examined, only in two of them (Netherlands, New Zealand), the concept of parliamentary inviolability does not exist. Parliamentary inviolability is applicable only in civil proceedings in five of the countries examined (Australia, Canada, Ireland, United Kingdom and USA), only in criminal proceedings in fourteen (Austria, Belgium, Finland, France, Germany, Greece, Iceland, Italy, Japan, Portugal, Spain, Sweden, Switzerland, Turkey), both in civil and criminal proceedings in four (Denmark, Israel, Luxemburg, Norway). In all countries where parliamentary inviolability is applicable only in criminal proceedings, the inviolability can be lifted by consent of Parliament. In cases of flagrante delicto, however, consent of the parliament is not necesssary. 


\section{Yasama Dokunulmazlığ (Bir Karşılaştırmalı Anayasa Hukuku İncelemesi)}

\section{Gỉiş}

$\mathrm{Bu}$ çalışmanın konusu yasama dokunulmazlığıdır. Ancak yasama dokunulmazlığını görmeden önce onun içinde yer aldığı yasama bağışıklğı kavramın kısaca görmek gerekir.

Yasama Bağışıklığı.- "Yasama bağışılığı (teşrî̂ muafiyet)" veya "parıâmenter bağışıllık (parliamentary immunity, immunité parlementaire)", parlâmento üyesinin görevini serbestçe yerine getirebilmesi amacıyla, onu hükamet tarafından veya özel kişiler tarafından başlatılabilecek olan adlî takiplerden koruyan ayricalıklar olarak tanumlanmaktadır (BARTHÉLEMY / DUEZ, 1933: 564; LAFERRIÉRE, 1947: 706). Yasama bağışılığının birinci çeşidi burada inceleyeceğimiz "yasama dokunulmazlığı"dır. Diğeri ise "yasama sorumsuzluğu"dur. O nedenle yasama dokunulmazlığını görmeden önce benzer kavram olan yasama sorumsuzluğu hakkında kısaca bilgi vermek uygun olacaktrr.

Yasama Sorumsuzluğu.- Bazılarının "mutlak dokunulmazlık" da dediği "yasama sorumsuzluğu (teşrî̂ mesuliyetsizlik)" veya "parlâmenter sorumsuzluk (parliamentary non-accountability, irresponsabilité parlementaire)" parlâmento üyelerinin yasama görevlerini yerine getirirken sarf ettikleri sözlerden, açıkladıkları düşüncelerden ve verdikleri oylardan dolayı herhangi bir hukukî veya cezaî takibata uğramayacakları anlamına gelir (PACTET, 1994: 414; VEDEL, 1949; 402; BARTHÉLEMY / DUEZ, 1933: 565; LAFERRIÉRE, 1947: 707). Yasama sorumsuzluğunun tanınmasındaki amaç, parlâmento üyelerinin yasama çalışmaları esnasındaki söz, düşünce ve oy hürriyetlerini tam olarak korumaktır. Bu sorumsuzluk sayesinde, parlâmento üyeleri hiçbir şeyden çekinmeyerek, düşüncelerini serbestçe açıklayacaklar, serbestçe oy kullanacaklardır. Millî irade parlâmentoda tam olarak ortaya çıkabilecektir (LAFERRIÉRE, 1947: 707; BARTHÉLEMY / DUEZ, 1933: 565; VEDEL / 1949: 402 / ÖZBUDUN, 2001: 277). Oy, söz veya düşünce açıklaması dışında kalan fiiller, yasama sorumsuzluğundan yararlanmazlar (LAFERRIÉRE, 1947: 711; BARTHÉLEMY / 
DUEZ, 1933: 567). Örneğin yasama çalışmaları sırasında, bir parlâmento üyesi, diğer bir parlâmento üyesini veya bir görevliyi döver, yaralar veya öldürürse, burada yasama sorumsuzluğu yoktur (BARTHÉLEMY / DUEZ, 1933: 567). Buna karşllık yapılan eylem, oy, söz ve düşünce açıklaması şeklinde ise içeriği ne olursa olsun yasama sorumsuzluğu kapsamina girer. Örneğin hakaret ve sövme fiilleri de meclis çalı̧̧maları sırasında işlenmek şartiyla kural olarak yasama sorumsuzluğu kapsamındadır (BARTHÉLEMY / DUEZ, 1933: 566). Zira hakaret ve sövme de sözle yapılan bir fiildir (DÖNMEZER / ERMAN, 1985: I, 251). Şüphesiz bir ülkenin anayasası küfür fiillerini yasama sorumsuzluğunun kapsamı dışında kaldığı öngörebilir ${ }^{1}$. Yasama sorumsuzluğu oy, söz veya düşünce açıklamasının "yasama çalışmaları" sırasında yapılmış olması şartıyla parlâmento üyelerine tam, mutlak bir koruma sağlar (ÖZBUDUN, 2000: 278; VEDEL, 1949: 402; LAFERRIÉRE, 1947: 711). Sorumsuzluğun mutlak nitelikte olması kendini şu dört noktada gösterir. (1) Yasama sorumsuzluğu parlâmento üyesini hem cezâ̂, hem de hukukî takibata karşı korur. (2) Yasama sorumsuzluğu kaldırılamaz. (3) Yasama sorumsuzluğu süreklidir. Yani yasama sorumsuzluğu kapsamına giren bir fiilinden dolay1, parlâmento üyesi hakkında, bu sıfatınu sona ermesinden sonra da hukukî veya cezaî bir takibatta bulunulamaz. (4) Yasama sorumsuzluğu kamu düzenine (ordre public) ilişkindir; vazgeçilemez (VEDEL, 1949: 402; VEDEL, 1949: 402; LAFERRIÉRE, 1947: 711-713; BARTHÉLEMY / DUEZ, 1947: 565-567; ARSEL: 1965, 258; ÖZBUDUN, 2000: 278).

\section{GENEL OLARAK YASAMA DOKUNULMAZLIĞI}

Burada önce yasama dokunulmazlığının genel olarak tanımını, anacını, kökenini, konusunu, sağladığı güvenceleri ve niteliğini göreceğiz.

1. Tanımı.- "Yasama dokunulmazlığ1 ${ }^{2}$ (teşrî̀ masûniyet)" veya "parlâmenter dokunulmazlık (parliamentary inviolability, inviolabilité parlementaire)", parlâmento üyeleri hakkında, suç işlediklerinden bahisle, parlâmentonun izni olmadan, gözaltına alma, tutuklama gibi bazı cezaî takibat işlemlerinde bulunulamayacağı anlamina gelmektedir. Yasama dokunulmazlığı, parlâmento üyeleri lehine tanunmış gerçek bir muafiyet konumundadır. Ceza kanunları karşısında vatandaşların eşitliği ilkesinin bir istisnası niteliğindedir (LAFERRIÉRE, 1947: 714). Bu nedenle de yasama dokunulmazlı̆̆ı zaman zaman birçok ülkede kamu oyunda tepki ile karşılanmaktadır. O nedenle yasama dokunulmazlığını amacının ortaya konulması gerekir.

2. Amac1.- Yasama sorumsuzluğunun amacl, parlâmento üyelerinin söz

1 Örneğin, Alman Anayasasının 46'ncı maddesinin birinci flkrası yasama sorumsuzluğuna ilişkin hükümlerin "hakaret ve sövmeye tatbik edilmeyeceği" açıç̧a öngörülmüştür.

2 Buna "nispî dokunulmazlık", "geçici dokunulmazlık", "muvakkat dokunulmazlık" diyenler de vardir. 
ve düşünce hürriyetlerini korumak olduğu halde, yasama dokunulmazlığının amacı, parlâmento üyelerinin parlâmento çalışmalarına istedikleri her zaman katılabilmelerini sağlamaktır. Yasama dokunulmazlığı olmazsa, parlâmento üyesi iktidar tarafından bir suç soruşturması bahanesiyle tutulabilir; mahkemeler tarafından tutuklanabilir. Bu durumda ise millî irade tam olarak parlâmentoda oluşamaz. Örneğin hükûmet aleyhine yapılan kritik bir güvensizlik oylamasında, birkaç muhalefet partisi üyesinin tutulma ve tutuklanma nedeniyle parlâmentoya gelip oy kullanamazsa, normalde düşmesi gereken hükûmet görevde kalabilir ki, bu demokrasiyle bağdaşmaz. İşte bu nedenle parlâmento üyelerine yasama dokunulmazliğ1 tanınmıştır. $O$ halde yasama dokunulmazlığının amac, parlâmento üyelerini iktidar tarafından tahrik edilebilecek keyfi, zamansız ve esassız ceza kovuşturmalarıyla, geçici bir süre için de olsa, yasama çalışmalarından alıkonulmasını önlemektir (ARSEL, 1965: 258; ÖZBUDUN, 2000: 279; LAFERRIÉRE, 1947: 714-715; VEDEL, 1949: 403).

3. Kökeni.- Yasama dokunulmazlığı Fransız kökenlidir. Fransız thtilalinden sonra toplanan Kurucu Meclis, 26-27 Haziran 1790 tarihli bir Kararname ile Meclis üyelerinin, Medisin karan olmaksızın ve "suçüstü (flagrant délit)" hâli hariç, tutuklanamayacağını öngörmüştür. Fransa'da yasama dokunulmazlğı ilkesi izleyen rejimler döneminde de kabul edilmiştir (LAFERRIÉRE, 1947: 716-717).

4. Konusu.- Yasama dokunulmazlığının konusu, aşağıda göreceğimiz Anglo-Sakson ülkeleri bir yana bırakılırsa parlâmento üyesinin işlediği suç teşkil ettiği iddia edilen fiillerdir. Bu fiiller, yasama fonksiyonunun ifası sırasında oy, söz ve düşünce açklaması şeklinde işlenmişse, bu fiiller, yasama dokunulmazlı̆gının değil, yasama sorumsuzluğunun kapsamına girerler. $O$ halde yasama dokunulmazlığını kapsamına giren filler, kural olarak parlâmento üyesinin görevi dışında işlediği cezaî sorumluluğunu doğurabilecek fillerdir.

5. Sağladığı Güvenceler.- Yasama dokunulmazlığı parlâmento üyesini bütün adlì takipten muaf tutmaz. Aşağıda ayrıca göreceğimiz gibi parlâmento üyesine karşı ceza davası açlamasa da hukuk davası açlabilir. Anglo-Sakson ülkeleri hariç, yasama dokunulmazlığı parlâmento üyesini kural olarak cezaî takipten korur. Ama her cezaî takip işlemine karşı da korumaz. Kural olarak, yasama dokunulmazlığı, parlâmento üyesinin yasama çalışmalarına katılmasını engelleyebilecek nitelikte olan, hürriyetten mahrum edici tedbirlere, yani tutma, gözaltuna alma, tutuklama, sorgulama, yargllama ve hapis cezasın infaz etme gibi işlemlere karşı güvence sağlar. Bu işlemlerin dışında kalan, parlâmento üyesinin hürriyetini kısıtlamayan yargısal işlemlerin yapılmasın kural olarak engellemez. Örneğin, savcı parlâmento üyesini ihzaren celp edemez; ama hakkında soruşturma açıp, delilleri toplayabilir. Yasama dokunulmazlığı kural 
olarak parlâmento üyesinin şahsını korur. O nedenle, ayrıca parlâmentonun iznine tâbi tutulmamş ise, genel hükümler dairesinde parlâmento üyesinin evinde arama yapılabilir (LAFERRIÉRE, 1947: 719). Ancak, evinde olup buna karşı koyan parlâmento üyesinin şahsı üzerinde zor kullanmak yine mümkün değildir (DÖNMEZER / ERMAN, 1985: I, 256). Anayasa ve kanunlarla aksi öngörülmedikçe parlâmento üyeleri tanuk sıfatıyla mahkemelerde dinlenebilir. Ancak parlâmento üyesinin tanik sıfatyyla da olsa ihzaren celp edilmesi mümkün değildir. Zira bu parlâmento üyesinin üzerinde hürriyeti kısıtlayıcı bir tedbirin uygulanması anlamuna gelir. Aşağıda ayrıntıların göreceğimiz gibi her ülkenin kendi anayasası ve kanunları parlâmento üyeleri hakkında hangi ceza soruşturması işlemlerinin yapılamayacağın ayrıca belirtmektedir.

6. Niteliği: Nispîdir.- Yasama dokunulmazlığı "nispî" nitelikte bir bağışıklıktır. Yasama dokunulmazlığının nispî olması şu anlamlara gelmektedir:

a) Aşağıda ayrıntılarını göreceğimiz gibi, Kara Avrupası hukuk sisteminde, yasama dokunulmazlığı parlâmento üyesini sadece ceza kovuşturmasına karşı korur. Hukuk davalarına karşı korumaz. Parlâmento üyesi hakkında ceza davası açılamasa da, suçtan zarar gören kişi hukuk davası açıp, tazminat isteyebilir. Keza parlâmento üyesi hakkında cebrî icra yoluna da gidilebilir (VEDEL, 1949: 403; LAFERRIÉRE, 1947: 718; BARTHÉLEMY / DUEZ, 1933: 570; DÖNMEZER / ERMAN, 1985: I, 256).

b) Yasama sorumsuzluğundan farklı olarak, yasama dokunulmazlığının istisnaları.i.yasama dokunulmazlyğynyn istisnalary; (derogations, dérogations) vardır: Genellikle suçüstü (cürm-ü meşhut, flagrante delicto, flagrant délit) hâli yasama dokunulmazlığını kapsamı dışında kalır (BARTHÉLEMY / DUEZ, 1933: 573-574; LAFERRIÉRE, 1947: 731). Yukarıda belirtildiği gibi yasama dokunulmazlığının amacl, parlâmento üyelerini hükâmet tarafından tahrik edilebilecek düzmece ve asılsız suç soruşturmalarına karşı korumaktır. Suçüstü hâlinde ise, parlâmento üyesinin suç işlediği apaçık ortadadır. Böyle bir durumda da parlâmento üyesine dokunulmazlık tanurması, parlâmento üyesine tanınmıs bir ayrıcalık durumuna gelir ki, bu yasama dokunulmazlığının amacıyla bağdaşmaz. O nedenle aşağıda örneklerini göreceğimiz üzere genellikle, suçüstü halinde işlenmiş suçların yasama dokunulmazlığının kapsamı dışında kaldığını anayasalar belirtmektedir.

c) Yasama dokunulmazlığı, yasama sorumsuzluğundan farkh olarak kaldırlabilir. Buna yine parlâmento üyesinin ait olduğu meclis karar verir. Buna "yasama dokunulmazlığınun kaldırılması (leave of parliamentary inviobility, levée de l'inviobilité parlementaire)" veya "kovuşturmaya izin (autorisation de poursuite)" karar1 ismi verilir (BARTHÉLEMY / DUEZ, 1933: 574-578; LAFERRIÉRE, 1947: 721-723; VEDEL, 1949: 401). Yasama dokunulmazlığı kaldırılmış olan parlâmento üyesinin parlâmento üyeliği kalkmıs olmaz. O sadece yargılama bakımından normal vatandaşlar gibi olur (GÖZLER, 2000: 329). 
d) Yasama sorumsuzluğundan farklı olarak, yasama dokunulmazlığı sürekli değildir; geçicidir (VEDEL, 1949: 403). Yani yasama dokunulmazlığı parlâmento üyeliği sıfatının devamı boyunca sürer. Parlâmento üyeliği sıfatı sona erince, parlâmento üyesi hakkında ceza kovuşturması yapılabilir. Daha önce verilmiş ceza hükmü çektirilir.

e) Aşağıda örneklerini göreceğimiz üzere birçok ülkede yasama dokunulmazliğı sadece parlâmentonun toplantı dönemlerinde (sessions) geçerli olmaktadır. Parlâmentonun tatil dönemlerinde bu dokunulmazlık işlememektedir (BARTHÉLEMY / DUEZ, 1933: 570; LAFERRIÉRE, 1947: 719). $\mathrm{Bu}$ tür düzenlemeler yasama dokunulmazlığının amacıyla uyuşum içindedir. Yasama dokunulmazlığının amacınun parlâmento üyesinin parlâmento çalışmalarına serbestçe katılmasıı sağlamak olduğuna göre, parlâmentonun zaten çalışmadığı dönemlerde böyle bir dokunulmazlığın tanınmasına gerek yoktur. Ancak bu sınrlama, toplant dönemleri (session) sisteminin uygulandığ ülkelerde geçerlidir. Parlâmentonun kısa bir tatil yaptığı ülkelerde bu yola genellikle gidilmemektedir.

f) Yasama dokunulmazlığı kamu düzenine (ordre public) ilişkindir (BARTHÉLEMY / DUEZ, 1933: 565; LAFERRIÉRE, 1947: 722). Yasama dokunulmazlığı, milletvekiline bir kişisel ayrıcalık olarak verilmemiştir. Onun görevini gereği gibi yapabilmesi için verilmiştir. Bu nedenle, parlâmento üyesi bu dokunulmazlıktan kendi isteğiyle vazgeçemez ${ }^{3}$. Vazgeçtiği yolundaki taahhütleri hükümsüzdür. Yasama dokunulmazlığın yargı organları re'sen dikkate almak zorundadırlar. Keza, yasama dokunulmazlı̆̆ı yargılamanın her safhasında ileri sürülebilir (LAFERRIÉRE, 1947: 722).

\section{DÜZENLEMELERI \\ II. YASAMA DOKUNULMAZLiĞI KONUSUNDA YíRMI BEŞ ÜLKENIN ANAYASAL}

Burada, yirmi beş ülkenin anayasal düzenlemelerinde yasama dokunulmazlığının nasıl düzenlendiğini göreceğiz. Bu yirmi beş ülke şu şekilde seçilmiştir: llk olarak Arend Lijphart'in demokratik olarak kabul ettiği yirmidört ülke ele alınmıştır (LIJPHART, Tarihsiz: 11-12, 36-39). Bu ülkeler şunlardır: Almanya, Amerika Birleşik Devletleri, Avustralya, Avusturya, Belçika, Danimarka, Finlandiya, Fransa, Hollanda, İngiltere, Irlanda, İspanya, Israil, Isveç, İsviçre, Italya, İzlanda, Japonya, Kanada, Lüksemburg, Norveç, Portekiz, Yeni Zelanda, Yunanistan. Bu ülkelerin ortak özellikleri, bu ülkelerdeki

3 Bunun tek istisnası Isviçre'dir. Isviçre'de Konfederasyon Lehine Siyasal ve Polis Garantileri Hakkında Federal Kanuna göre yasama dokunulmazlığının kaldırılmasına bizzat parlâmento üyesinin kendisi de izin verebilmektedir (Loi fédérale sur les garanties politiques et de police en faveur de la Confédération; http://www.ipu.org/parline-f/reports/1303.htm, 1.5.2001). 
demokratik rejimlerin az çok uzunca bir zamandan beri kesintisiz olarak sürmüş olmasıdır (LIJPHART, Tarihsiz: 36). Bu yirmi dört kendi ülkemiz olan Türkiye'yi de ilâve ettik. Böylece yirmi beş ülkelik bir liste oluşturduk.

1. A.B.D. ${ }^{4}-1787$ Amerika Birleşik Devletleri Anayasasının ${ }^{5}$ 1'inci maddesinin 6'ncı bölümünün l'inci fıkrasina göre, "Senatörler ve temsilciler... ihanet (treason), cürüm (felony) ve asayişi ihlâl (breach of the peace) hâli dışında, kendi Meclislerinin toplantılarına katıldıkları sırada, gerekse bu toplantılara gelir veya giderken tutuklanmama imtiyazından yararlanurlar". Amerika Birleşik Devletlerinde bu hükme "tutuklanma hükmü (arrest clause)" (TRIBE, 2000: I, 1012), bu hükümle öngörülen imtiyaza ise "tutuklanmama imtiyazı (privilege from arrest)" (NOWAK / ROTUNDA / YOUNG, 1978: 242) ismi verilmektedir. Tutuklanmama imtiyazı her zaman aşırı dar yoruma (exceedingly narrow interpretation) tâbi tutulmuştur (NOWAK / ROTUNDA / YOUNG, 1978: 242). Zira, 1787 Amerika Birleşik Devletleri Anayasasının yazıldığı dönemde, "hukuk davalarından (civil cases) dolayı da kişilerin tutuklanması ve hapse atılması mümkünđü. İşte 1787 Amerika Birleşik Devletleri Anayasasın yazanlar Kongre üyelerinin hukuk davalarından dolayı tutuklanmamaları için bu imtiyazı getirmişlerdir (NOWAK / ROTUNDA / YOUNG, 1978: 242). Oysa günümüzde, hukuk davalarından dolayı kişilcrin tutuklanması (civil arrest) uygulaması yürürlükten kalktığından (TRIBE, 2000: I, 1012), bu hüküm, yani arrest clause (m.1, b.6, f.1) anlamsız kalmıştır (NOWAK / ROTUNDA / YOUNG, 1978: 242). Özetle Amerika Birleşik Devletlerinde Kongre üyelerinin işledikleri suçlardan dolayı her türlü ceza davasında (criminal case) tutuklanmaları mümkündür (NOWAK / ROTUNDA / YOUNG, 1978: 242). Gerçekten de Amerika Birleşik Devletleri Yüksek Mahkemesi, Williamson v. United States (207 U.S. 425, 1908) kararında yalancı şahitlikten mahkûm olan Temsilciler Meclisinin bir üyesinin tutuklanmama imtiyazından yararlanamayacağına hükmetmiştir (TRIBE, 2000: I, 1012). Özetle Amerika Birleşik Devletlerinde cezaî alanda Kongre üyelerine tanınan bir dokunulmazlığın bulunmadığın söyleyebiliriz. Keza, Amerika Birleşik Devletlerinde Kongre üyeleri mahkemelere tank sıfatıyla çağrılabilir (http://www.ipu.org/parline-f/reports/ 1339.htm, 1.5.2001).

2. Almanya. ${ }^{6}-1949$ Alman Anayasas1 ${ }^{7}$ yasama dokunulmazlı̆ (immunität) kurumunu kabul etmiştir. 1949 Alman Anayasasının 46'ncı

4 Amerika Birleşik Devletlerinde yasama dokunulmazlı̆̆ hakkında bkz:: TRIBE, 2000: I, 1011-1013; NOWAK / ROTUNDA / YOUNG, 1978: 236-242; WILSON / DIIULIO, 1995: 300; http://www.ipu.org/parline-f/reports/1339.htm (1.5.2001).

517 Eylül 1787 tarihli Amerika Birleşik Devletleri Federal Anayasasının Ingilizce metni için bkz.: http://www.constitution. org/ constit_htm (1.2.2001).

6 Almanya'da yasama dokunulmazlığı hakkında bkz.: AUTEXIER, 1997: 37-38; http://www.ipu.org/parline-f/reports/1121.htm (1.5.2001).

723 Mayıs 1949 tarihli Alman Anayasasının 107'nci maddesi yasama dokunulmazlığın düzenlemektedir (http://www.ipu.org/parline-f/reports/1121.htm (1.5.2001). 
maddesinin ikinci fıkrasına göre ${ }^{8}$ Bundestag üyeleri Bundestag'ın izni olmaksızın, cezay1 gerektiren bir fiilden dolayı cezâ̂ takibata uğrayamaz veya tutuklanamazlar. Bununla birlikte suçüstü hâlinde veya ertesi gün yakalanmı̧ olması durumunda Bundestag üyeleri yasama dokunulmazlığından yararlanamazlar. Keza aynı maddenin üçüncü fikrasına göre, Bundestag üyelerinin başka bir şekilde kişisel özgürlüklerini kısıtlanması için Bundestag'ın izni gerekir. Anayasa aynca, bir milletvekili hakkındaki her türlü ceza davasınn, milletvekilinin hürriyetini kısıtlayıa her türlü tedbirin Bundestag'ın istemesi durumunda kaldırılmasın öngörmektedir (m.46/4). Bundestag üyeleri tanuk sifatiyla mahkemelerde dinlenilebilir. Bununla birlikte, Ceza Usal Kanunu (m.50/1) ve Medenî Usâl Kanununa (m.382/2) göre Bundestag üyeleri tanik olarak toplantı döneminde Bundestag'ın bulunduğu yerde dinlenilmelidirler (http://www.ipu.org/parline-f/reports/1121.htm, 1.5.2001). Yasama dokunulmazlığ Bundestag üyesinin seçilmesinden görev süresinin sonuna kadar işler (Ibid.). Seçimden önce başlatılmış soruşturmaları da kapsar (Ibid.). Yani bunlardan dolayı da Bundestag üyesi tutuklanamaz. Yasama dokunulmazlığının kaldırilması konusunda yetkili makam Bundestag veya onun Dokunulmazlık Komisyonudur (Ibid.). Dokunulmazlığı kaldırılan Bundestag üyesi bu kararın iptali için Anayasa Mahkemesine başvurabilir (Ibid.). Bundestag üyelerinin ikametgahlarında arama yapılabilmesi için de Bundestag'ın izni gerekir (Ibid.). Almanya'da ikinci Meclis olan Bundesrat üyelerinin yasama dokunulmazliğ yoktur (Ibid.); zira Bundesrat üyeleri parlâmenter değildir; federe devlet (Länder) hükametlerinin üyesidirler (GREWE / RUIZ FABRI, 1995: 442).

3. Avustralya.- 1900 Avustralya Anayasasınin ${ }^{9} 49^{\prime}$ uncu seksiyonuna göre, Temsilciler Meclisi ve Senato üyelerinin imtiyazları (privileges) ve dokunulmazlıkları (immunities) Parlâmento tarafından düzenleneceği şekilde olacaktır. Bu zamana kadar, bunlar Birleşik Krallık Avam Kamarası üyelerininki gibi olacaktır. Avustralya'da yasama dokunulmazlığ 1987 tarihli Parliamentary Privilege Act ile düzenlenmiştir (http://www.ipu.org/parline-f/reports/ 1015.htm, 1.5.2001). Bu Kanuna göre, yasama dokunulmazlığı cezaî alanda değil, hukukî (civil) alanda geçerlidir (lbid.). Bu alanda Parlâmento üyesine mutlak bir koruma sağlar. Parlâmento üyesi tutuklanamaz ve hapsedilemez (Ibid.). Parlâmento üyesinin sahip olduğu bu dokunulmazlık kaldırlamaz. Keza bu alanda Parlâmento üyesi yargılanamaz; keza tanık olarak veya jüri üyesi olarak bir mahkemeye çağrilamaz (Ibid.). Yasama dokunulmazlığı sadece Parlâmentonun toplantı dönemleri (sessions) süresince ve bu dönemlerin beş gün öncesi ve sonrasını kapsar (Ibid.). Cezaî alanda yasama dokunulmazlığı işlemez.

8 Keza Bundestag Içtüzüğünün 107'nci maddesi yasama dokunulmazlığın düzenlemektedir (http://www.ipu.org/parline-f/reports/1121.htm (1.5.2001s.

91900 Avustralya Anayasasının Ingilizce metni için bkz.: http://www.uni-wuerzburg. de/law/as00000_. html (1.2.2001). 
Bununla birlikte konvansiyonel nitelikte bir kurala göre Parlâmento üyesi hakkunda yapilan soruşturmadan haberdar edilmesi gerektiği kabul edilmektedir (Ibid.).

4. Avusturya.- 1929 Avusturya Anayasasınun ${ }^{10} 57$ 'nci maddesinin ikinci fikrasına göre ${ }^{11}$ Millî Meclis (Nationalrat) üyeleri, suçüstü hâli hariç, ancak Millî Meclisin izniyle tutuklanabilirler. Keza ayn fıkraya göre, Millî Meclis üyelerinin evlerinin aranabilmesi için de Millî Meclisin izni gerekir (m.57/2). Avusturya'da Millî Meclis üyelerinin işlediği suç "üyenin siyasî faaliyetleriyle açıkça bağlantısız (manifestly not connected to the political activity of the member)" ise üye hakkında cezaî takip yaplabilmesi için yasama dokunulmazlığının kaldırılmasına gerek yoktur. Ancak, söz konusu üye veya Meclisin bu konularla görevli Daimî Komitesinin üyelerinin üçte biri talep ederse, ilgili makam, Millî Meclisten, üyeye atfettiği suçun onun siyasî faaliyetleriyle bağlantısız bulunduğu konusunda bir karar almak zorundadır. Böyle bir talep olduğunda, soruşturma sürecindeki bütün işlemler o aşamada durur (m.57/3). Millî Meclis bu talep konusunda sekiz hafta içinde karar vermemiş ise, gerekli izni verdiği varsayılır (m.57/4). Eğer Millî Meclis üyesi, suçüstü halinde yakalanırsa, yetkili makam derhal Millî Meclis başkanına üyenin tutuklandığın bildirir (m.57/5). Eğer Millî Meclis veya toplant halinde değilse Daimî Komite talep ettiğinde, tutuklama kaldırılır veya kanunî süreç bir bütün olarak düşürülür (m.57/5). 1929 Avusturya Anayasasına göre, Millî Meclis üyelerinin dokunulmazlıkları yeni Millî Meclisin toplandığı gün sona erer (m.57/6). Millî Meclis üyeleri tanık sıfatıyla mahkemelere çağrılabilirler (http://www.ipu.org/parline-f/reports/ 1017.htm, 1.5.2001). Millî Meclis üyeleri yasama dokunulmazlığından milletvekilliğinin başlamasından sona ermesine kadar devam eder (Ibid.).

5. Belçika.- 1994 Belçika Anayasasına göre ${ }^{12}$, suçüstü hâli (flagrant délit) hariç, Parlâmento üyeleri toplantı dönemi (session) boyunca, cezaî sahada, ait olduğu meclisin izni olmadıkça, bir mahkeme veya divan önüne gönderilemez veya doğrudan celp edilemez veya tutuklanamaz (m.59/1). Meclis bu izni (yani dokunulmazlığın kaldırılması kararı) hakkında ilgili parlâmento üyesinin başvuru hakkı yoktur (http://www. ipu.org/parline-f/reports/1029.htm, 1.5.2001). Suçüstü hâli hariç, cezaî sahada bir hakimin müdahalesini gerektiren zorlayıcı tedbirlerin uygulanmasina Meclis üyeleri hakkında toplantı dönemi süresince yetkili hakimin istemi üzerine Istinaf Mahkemesi Biriñci Başkan

101929 Avusturya Anayasasının (Bundes-Verfassungsgesetz in der Fassung oon 1929) Ingilizce çevirisi için bkz.: http://www.uni-wuerzburg.de/law/as00000_html

11 Yasama dokunulmazlığı keza Millî Konsey lçtüzüğü Hakkında Federal kanunun 10'uncu maddesinin ikinci fıkrasiyla düzenlenmiştir (http://www.ipu.org/parline-f/reports/ 1017.htm (1.5.2001).

1217 Şubat 1994 tarihli Belçika Anayasasının Fransızca aslı için bkz.: http://www.senate.be/ senbeldocs/ constitution/ const_fr.html (1.2.2001); Ingilizce çeviri metni için bkz.: http://www.uni-wuerzburg.de/ law/ be00000_html. (1.2.2001). 
tarafından karar verilebilir. Bu karar ilgili Meclisin başkanuna iletilir (1994 Belçika Anayasası, m.59/2). Arama (perquisition) ve el koyma (saisie) ancak Meclis Başkanının veya onun tarafından tayin edilmiş üyenin huzurunda yapılır (m.59/3). Toplant dönemi süresince sadece savcllik görevlileri ve yetkili memurlar bir Meclis üyesi hakkında cezaî sahada kovuşturma açabilirler (m.59/4). Hakkında cezaî sahada soruşturma açlan Meclis üyesi, toplantı dönemi süresince, ait olduğu Meclisten hakkında yapılan kovuşturmanın durdurulmasına karar verilmesini isteyebilir. Ilgili Meclis bu konudaki kararın kullanılan oyların üçte iki çoğunluğuyla alabilir (m.59/5). Keza Meclis kendi üyesinin tutukluluğu veya bir mahkeme tarafindan yargılanması askıya alınmasına da karar verebilir (m.59/son). Parlâmento üyeleri tanık sıfatyyla mahkemelere çağrlabilirler (http://www.ipu.org/parline-f/reports/1293.htm, 1.5.2001).

6. Danimarka.- 1953 Danimarka Anayasasınun ${ }^{13} 57$ 'nci seksiyonuna göre, Parlâmentonun hiçbir üyesi, suçüstü (flagrante delicto) hâlinde yakalanması durumu hariç, Parlâmentonun izni olmaksızın hiçbir şekilde soruşturulamaz ve hapsedilemez. Danimarka'da yasama dokunulmazlığ hem hukukî, hem de cezaî alanda geşerlidir; yani parlâmento üyelerini hem hukuk, hem de ceza kovuşturmalarına karşı korur (http://www. ipu.org/parline-e/reports/ 2087.htm, 1.5.2001). Parlâmento üyesi tutuklanamaz, göz altına alınamaz. Keza parlâmento üyesi hakkında dava da açlamaz (Ibid.). Ancak yasama dokunulmazlığı Danimarka'da aramalara karşı güvence sağlamaz (Ibid.). Keza Parlâmento üyesi tanık sifatıyla mahkemelere çağnlabilir (Ibid.). Yasama dokunulmazlı̆̆ı parlâmento üyesinin seçilmesinden görevinin sona ermesine kadar devam eder (lbid.). Yasama dokunulmazlığı Parlâmento (Folketing) tarafından kaldırılabilir. Parlâmento üyesinin kaldırılma sürecinde dinlenilmesi gerekli değildir. Keza Parlâmento üyesinin kaldırma kararına karşı başvuru hakkı yoktur (Ibid.).

7. Finlandiya.- 1999 Finlandiya Anayasasınun ${ }^{14} 30^{\prime}$ uncu seksiyonuna göre, bir milletvekili, milletvekilliği görevlerini yerine getirmekten engellenemez. Bir milletvekili Parlâmentoda kullanılan oyların altıda beşiyle alınmış bir kararla izin verilmedikçe mahkeme önüne çıartılamaz veya özgürlügünden mahrum birakulamaz (1999 Finlandiya Anayasası, seksiyon 30/2). Bir milletvekili tutuklanırsa veya gözaltına alınırsa bu durum derhal Parlâmento Başkanına bildirilir. En az altı ay hapis cezasıyla cezalandırılan bir suçu işlediğine ilişkin esaslı sebepler yoksa, bir milletvekili dava başlamadan önce Parlâmentonun rizası olmaksızın tutuklanamaz (sek.30/3).

135 Haziran 1953 tarihli Danimarka Anayasasının Ingilizce çeviri metni için bkz.: http://www.uni-wuerzburg.de/ law/da00000_html (1.2.2001).

1411 Haziran 1999 tarihli Finlandiya Anayasasının Ingilizce çeviri metni için bkz.: http://www.om.fi/ constitution/ 3340.htm (1.2.2001). 
8. Fransa. ${ }^{15}$ - 1958 Fransız Anayasasınun ${ }^{16} 26$ 'no maddesinin 4 Ağustos 1995 tarih ve 95-880 sayllı Anayasal Kanun ${ }^{17}$ değiştirilmis şekline göre, ağır suçlar ve orta ağırlıktaki suçlar alanunda (en matière criminelle ou correctionnelle) ${ }^{18}$ hiçbir Parlâmento üyesi ait olduğu Meclisin Başkanlık Divanunin (Bureau de l'Assemblée) izni olmadıkça tutuklanamaz veya hakkında diğer hürriyeti sinurlandirıa veya mahrum edici bir tedbir uygulanamaz (1958 Fransiz Anayasası, m.26/2). Suçüstü (crime ou délit flagrant) veya kesin hükümle mahkamiyet (condamnation définitive) hâlinde bu izin gerekmez (m.26/2). Bir parlâmento üyesi hakkında gözalth, hürriyeti sınırlandırıcı veya mahrum edici tedbirler veya soruşturma, Meclis talep ettiğinde, Meclisin toplant dönemi (session) süresince askıya alınır (m.26/3). Parlâmento üyeleri tanık sıfatıyla mahkemelere çağrilabilirler (http://www.ipu.org/parline-f/reports/1113.htm, 1.5.2001).

Fransa'da 1995 'ten önce toplantı döneminde Parlâmento üyeleri hakkında (hürriyeti sınırlandırıcı tedbirler uygulanmadan) soruşturma açlması dahi Parlâmentonun iznine bağlıydı (LAVROFF, 1995: 455; PACTET, 1994: 415; TURPIN, 1994: 438-441). 1995 değişikliğinden sonra, Parlâmento üyeleri hakkında soruşturma açlabilecek, evinde arama yapılabilecek, Parlâmento üyesi yargllanabilecek, ancak Parlâmento üyesi hakkında "tutuklama (arrestation)" ve "hürriyetten mahrum edici veya hürriyeti sinurlayıcı bütün diğer tedbirler (toute autre mesure privative ou restrictive de liberté)" Parlâmentonun izni olmadıkça uygulanamayacaktır (FAVOREU vd. 1998: 670; GICQUEL, 1999: 638). 1995 değişikliğinin gètirdiği diğer bir yenilik de, izin verme yetkisinin Meclisin kendisinden alınarak Meclis Başkanlık Divanuna (Bureau de l'Assemblée) verilmesidir.

9. Hollanda.- 1983 Hollanda Anayasasında ${ }^{19}$ yasama sorumsuzluğuna ilişkin hüküm (m.71), bulunmasına rağmen, yasama dokunulmazlığına ilişkin

15 Fransa'da yasama dokunulmazlığı hakkında bkz: FAVOREU vd. 1998: 670-671; ARDANT, 1996: 514-515; CHAGNOLLAUD, 1999: 326-327; GICQUEL, 1999: 637; http://www.ipu.org/parline-f/reports/1113.htm (1.5.2001).

164 Ekim 1958 tarihli Fransız Anayasasının Fransızca aslı için bkz.: http://www.legifrance. gouv.fr/html/frame_ constitution.htm (1.2.2001); Ingilizce çeviri metni için bkz.: http://www. assemblee-nationale.fr/ 8/8ab.htm (1.2.2001).

17 Loi constitutionnelle $n^{\circ} 95-880$ du 4 août 1995 (Journal officiel du 5 août 1995).

18 "En matière criminelle ou correctionnelle (criminel veya correctionnel alanda)" ifadesini Türkçe'ye çevirmek mümkün değildir. Criminal, crime niteliğinde suçlarla ilgili demektir. Bunlar "ağır suçlar"dır. Correctionnel ise délit niteliğinde suçlarla ilgili demektir. Delit kelimesini Türkçe'ye "suç" olarak çevirenler varsa da bu doğru değildir. Délit ağır suçlar ve kabahatler dışında kalan "orta ağırıkta suçlar"dır. Yani Fransa'da "kabahatler (contraventions)" yasama dokunulmazlığından yararlanmazlar. Keza "hukukî takipler (poursuites civiles)" hakkında da yasama dokunulmazlığı işlemez.

1917 Şubat 1983 tarihli Hollanda Anayasasının Ingilizce çeviri metni için bkz.: http://www.uni-wuerzburg.de/law/nl00000_html (1.2.2001). 
bir hüküm bulunmamaktadır. Hollanda'da yasama dokunulmazlığ $\tilde{\gamma}_{\text {yoktur }}$ (GREWE / RUIZ FABRI, 1995: 443). Bununla birlikte, Parlâmento üyesinin tutuklanması veya hapsedilmesi halinde parlâmento üyesinin Parlâmento toplantilarına katılmasina izin verilebilir (http://www.ipu.org/parline-e/ reports/2231.htm, 1.5.2001).

10. Ingiltere.- Ingiltere'de tarihsel olarak Parlâmento üyeleri tutuklanmama hürriyetine (freedom from arrest) sahip olduklan ve bu imtiyazin Parlâmentonun toplanth döneminde ve bu dönemden önceki ve sonraki kurk günü kapsadığ1 kabul edilmektedir (HOOD PHILLIPS / JACKSON, 1987: 241). Ancak Ingiltere'de bu tutuklanmama imtiyazı, sadece hukuk davalarında (civil proceedings) geçerlidir (DE SMITH / BRAZIER, 1989: 322). Yani Parlâmento üyelerinin borçlarından dolayı tutuklanması (civil arrest) mümkün değildir (DE SMITH / BRAZIER, 1989: 322; HOOD PHILLIPS / JACKSON, 1987: 241). 1770 tarihli Parliamentary Privilege Act'a göre dokunulmazlık sadece parlâmento üyesine tutuklanmama ve hapsedilmeme güvencesi sağlar (http://www.ipu. org/parline-e/reports/2335.htm, 1.5.2001). Bununla birlikte mahkemeye hakaret (contempt of court) suçunda Parlâmento üyesinin tutuklanabileceği kabul edilmektedir (Ibid.). Avam Kamarası üyeleri mahkemelere tanık olarak çağrılabilir. Ancak Speakers üyenin Avam Kamarası toplantısına katılması gerektiğini bildirirse, Avam Kamarası üyesi tanık olarak da çağrlamaz (Jbid.). Ingiltere'de yasama dokunulmazlığı kaldırılamaz. Tekrar hatırlatalım ki, Ingiltere'de dokunulmazlık sadece medenî (civil) alandadır. Ingiltere'de hiçbir zaman ceza davalarından (criminal proceedings) dolayı Parlâmento üyelerinin tutuklanamayacağı fikri kabul edilmemiştir (HOOD PHILLIPS / JACKSON, 1987: 241). Ingiltere'de bir Parlâmento üyesi bir suç işlerse, herkes gibi tutuklanabilir ve yargılanabilir (Ibid.: 242). Ayrıca belirtelim ki, Ingiltere'de kişilerin borçlarından dolayı hapsedilmesi (imprisonment for debt) 1869 tarihli Debtors Act ile ilga edildiğinden "tutuklanmama hürriyeti"nin hukuk davaları bakımından da bir anlamı kalmamıştır (Ibid.).

11. İrlanda.- 1937 Irlanda Anayasasına ${ }^{20}$ göre, Parlâmentonun her iki Meclisinin üyeleri, "ihanet (treason)", "cürüm (felony) ve "aşayişi bozma (breach of the peace)" suçları hariç, Parlâmento toplantılarına gelip giderken ve seçim bölgelerinde iken tutuklanmama imtiyazına (privilege from arrest) sahiptirler (m.14/13). Görüldüğü gibi İrlanda Anayasasınn hükmü, 1787 Amerika Birleşik Devletleri Anayasasındaki arrest clause'a ve Ingiltere'deki teamülî kurala (freedom from arrest) büyük ölçüde benzemektedir. Irlanda'da yasama dokunulmazlığının cezaî alanda değil, hukukî alanda mevcut olduğunu söyleyebiliriz. Irlanda'da parlâmento üyeleri suçlarından dolayı tutuklanabilecek ve yargulanabileceklerdir.

201 Temmuz 1937 tarihli Irlanda Anayasasının Ingilizce ash için bkz.: http://www.math.tcd.ie/pub/ Constitution.html (1.2.2001). 


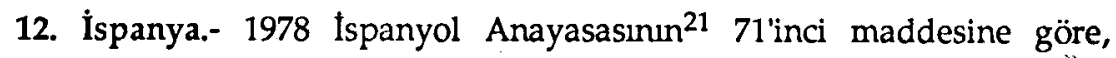
milletvekilleri ve senatörler vekâlet sürelerince dokunulmazlıktan (inmunidäd) yararlanurlar ve sadece suçüstü (flagrante delito) hâlinde tutuklanabilirler. Milletvekilleri ve senatörler, ait oldukları Meclislerin ön izni (previa autorización) olmaksızın tutuklanamazlar; gözaltına alınamazlar; haklarında soruşturma açlamaz ve yargılanamazlar (m.71/2). Bu izin, yani dokunulmazlığın kaldırlması kararı alınurken parlâmento üyesi dinlenir. Ancak parlâmento üyesinin alınan karara karşı başvuru hakkı yoktur (http://www.ipu.org/ parline-f/reports/1293.htm, 1.5.2001). Bununla birlikte milletvekili ve senatörlerin ikametgahlarında arama yapılabilir (Ibid.). Milletvekilleri ve senatörlere karşı açılan davalar hakkında Yüksek Mahkemenin Ceza Dairesi (Sala de lo Penal del Tribunal Supremo) yetkili olacaktır (m.71/3). Milletvekilleri ve Senatörler tanık sıfatıyla mahkemeye çağrılabilirler (lbid.).

13. İsrail. ${ }^{22}-12$ Şubat 1958 tarihli Knesset Hakkında İsrail Temel Kanununun $^{23}$ 17'nci seksiyonu, Knesset üyelerinin dokunulmazlık sahibi olacakların belirtmekte ve ayrıntıların kanunlar düzenleneceğini hükme bağlamaktadır. Bu düzenleme 1951 tarihli Knesset Üyelerinin Dokunulmazlıkları, Hakları ve Ödevleri Hakkında Kanun ${ }^{24}$ ile düzenlenmiştir. Bu Kanuna göre, yasama dokunulmazlığı, hem hukukî ve hem de cezaî alanda uygulanmaktadır (http://www.knesset.gov.il/knesset/knes/eng_work_chak1.htm, 1.5.2001). Yasama dokunulmazlığı, milletvekillerini tutuklanmaya, gözaltına alınmaya, hakkında hukuki takip yapılmasına ve evlerinde arama yapilmasina karsı korumaktadır (http://www.ipu.org/parline-f/reports/1155.htm, 1.5.2001). Israil'de yasama dokunulmazlığ oldukça geniş kapsamlıdır. Bununla birlikte, kuvvet kullanarak icra edilen, kamu düzenini bozan ve ihanet oluşturan fillerin suçüstü halinde işlenmesi durumunda milletvekili tutuklanabilir ve gözaltına alınabilir (1951 tarihli Knesset Üyelerinin Dokunulmazlıkları, Hakları ve Ödevleri Hakkında Kanun, m.3; http://www. ipu.org/parline-f/reports/ 1155.htm, 1.5.2001). Yasama dokunulmazliğı milletvekilinin seçilmesinden görev süresinin sona ermesine kadar koruma sağlamaktadır. İsrail'de yasama dokunulmazlığı kaldırılabilir niteliktedir. Kaldırmaya yetkili makam, Knesset veya Knesset'in Parlâmento İşleri Komitesidir. Dokunulmazliğı kaldırılan milletvekili dinlenir. Ancak milletvekili kaldırma kararına karşı başvuru hakkı yoktur (Aynı Kanun, m.13; http://www.ipu.org/parline-f/reports/1155.htm, 1.5.2001).

2129 Aralık 1978 tarihli Ispanyol Anayasasının Ingilizçe çeviri metni için bkz.: http://www.uni-wuerzburg.de/law/sp00000_html

$22 \mathrm{http}: / /$ www.ipu.org/parline-f/reports/1155.htm (1.5.2001); http://www.knesset. gov.il/knesset/knes/eng_work_chak1. htm (1.5.2001).

2312 Şubat 1958 tarihli Knesset Hakkında Israil Temel Kanununun Ingilizce çevirisi hakkında bkz.: http://www.uni-wuerzburg.de/law/is0000_.html (2.1.2001).

24 Bu Kanun hakkında bkz. http://www.knesset.gov.il/knesset/knes/eng_work_chak1. htm (1.5.2001). 
14. İsveç.- 1975 Isveç Anayasasının 25 3'üncü Bölümünün 8'inci maddesine göre, Parlâmentonun toplantıya katılan ve oy veren üyelerin en az altıda beşinin kabul edeceği bir kararla izin verilmedikçe, kimse bir parlâmento üyesinin görevini yerine getirirken yaptığı eylemlerden ve söylediği sözlerden dolayı ona karşı dava açamaz veya onu özgürlüğünden mahrum bırakamaz veya onun ülke içinde seyahat etmesini engelleyemez (b.3, m.8/1). Bir Parlâmento üyesinin bir suç işlediğinden şüphelenilmesi durumunda, tutuklama, gözaltına alma veya hapse ilişkin kanun hükümlerinin Parlâmento üyesi hakkında uygulanabilmesi ancak onun suçluluğunu kabul etmesi veya suçüstü halinde yakalanması veya işlediği suçun minimum cezasının iki yıl hapisten fazla olması durumunda mümkündür (b.3, m.8/2). Parlâmento üyesi tanık sıfattyla mahkemelere çağrlabilir (http://www.ipu.org/parline-f/reports/1303.htm, 1.5.2001). Isveç'te yasama dokunulmazlığı milletvekilinin seçilmesinden görev süresinin bitimine kadar devam eder (Ibid.).

15. İsviçre.- 1999 İsviçre Anayasasının ${ }^{26} 162$ 'nci maddesinin ilk fikrası, Federal Parlâmento üyelerinin Parlâmentoda yaptıkları konuşmalardan dolayı sorumlu olmadikların öngörmekte, ikinci flkrası ise dokunulmazlığın diğer şekillerinin ise kanunla düzenlenmesini öngörmektedir. İsviçre'de yasama dokunulmazlığı, Konfederasyon Lehine Siyasal ve Polis Garantileri Hakkında Federal Kanun ${ }^{27}$ ile düzenlenmiştir. Bu Kanuna göre, İsviçre'de yasama dokunulmazhı̆ı sadece cezaî alanda geçerli olmakta ve bütün suçları için parlâmento üyesini tutuklamaya, gözaltına almaya, hakkında soruşturma açılmasına ve evinde arama yapılmasına karşı korumaktadır (http:// www.ipu.org/parline-f/reports/1303.htm, 1.5.2001). Bununla birlikte parlâmento üyesi, kaçma şüphesi altında gözaltına alınabilir. Keza, suçüstü halinde cürüm (ağır suçlar) işlenmesi durumunda parlâmento üyesi geçici olarak tutuklanabilir. Ancak bu konudaki ya Parlâmento üyesinin kendi rızası veya Millî Meclisin (Conseil national) izni 24 saat içinde alınmalıdır (Aynı Kanun, m.1/2). Yasama dokunulmazlığ parlâmento üyesinin tanı sıfatıyla * Parlâmentoya çă̆nlmasın engellemez (http://www.ipu.org/ parline-f/ reports/1303.htm, 1.5.2001). İsviçre'de yasama dokunulmazhğı Millî Meclisin izniyle veya Parlâmento üyesinin bizzat kendi izniyle kaldırılabilir (Ibid.). Yasama dokunulmazlı̆gnın kaldırılması sürecinde Parlâmento üyesi dinlenir ve parlâmento üyesinin yasama dokunulmazlığının kaldırılmasına karşı itiraz hakkı vardır (Ibid.). Parlâmento üyesinin geçici olarak gözaltına (détention

251 Ocak 1975 tarihli Isvę̧ Anayasasını Ingilizce çeviri metni için bkz.b: http://www.uni-wuerzburg.de/ law/sw00000_html (1.2.2001).

$2614 \mathrm{Nisan} 1999$ tarihli Isviçre Anayasasının Fransızca ashı için bkz.: http://www.admin.ch/ $\mathrm{ch} / \mathrm{f} / \mathrm{rs} / 101 /$ index.html (1.2.2001); Ingilizce çeviri metni için bkz.: http:/ / www.uni-wuerzburg.de/ law/ sz00000_. html (1.2.2001).

27 Loi fédérale sur les garanties politiques et de police en faveur de la Confédération (http://www.ipu.org/ parline-f/reports/1303.htm (1.5.2001s s. 
préventive) alınması durumunda Millî Meclisin talebi üzerine parlâmenterlerin Parlâmento toplantılarına katılmalarına izin verilebilir (Ibid.). Yasama dokunulmazlığı Isviçre'de sadece toplantı dönemlerinde işler (Ibid.).

16. İtalya.- 1947 Italyan Anayasasının ${ }^{28}$ yasama dokunulmazlığın düzenleyen 68'inci maddesi, 30 Ekim 1993 tarihli Anayasal Kanun ile değiştirilmiştir ${ }^{29}$. Maddenin yeni şeklinin ikinci fikrasına göre, Parlâmento üyesinin tutuklama kararı gerektiren bir suçu işlerken, suçüstü halinde yakalanması durumu hariç, hiçbir Parlâmento üyesi, ait olduğu Meclisin izni olmaksızın tutuklanamaz, kişisel hürriyetinden mahrum bırakılamaz, gözaltına alınamaz ve keza Parlâmento üyesinin şahsı veya ikametgahu aranamaz (m.68/2). Ancak kesin mahkâmiyet hükmünün infazı hâli bu hükmün dışındadır (m.68/2). Aynı maddenin ü̧̧üncü fıkrasına göre, benzer bir izin, Parlâmento üyelerinin konuşmalarının veya haberleşmelerinin dinlenebilmesi ile mektuplarına veya yazışmalarına el konulabilmesi için de gereklidir. Buna göre, parlâmento üyeleri tutuklanamaz; ancak haklarında soruşturma açılabilir. Parlâmento üyeleri tank olarak mahkemelere çağrılabilirler (http:// www.ipu.org/parline-e/reports/2157.htm, 1.5.2001).

17. İzlanda.- 1944 İzlanda Anayasasınin ${ }^{30} 49^{\prime}$ uncu maddesine göre, Althingi'nin hiçbir üyesi, suç işlerken yakalanması durumu dışında, Althingi'nin toplantı dönemi (session) boyunca, Althingi'nin izni olmaksızın hapsedilemez veya hakkında bir cezaî kovuşturma işlemi yapılamaz.

18. Japonya.- 1946 Japon Anayasasınun ${ }^{31} 50$ 'nci maddesine göre, kanunla öngörülen hâller hariç olmak üzere, her iki Meclisin üyeleri, Dietin toplantı döneminde tutuklanmaktan muaftırlar. Tutuklanan üyeler, Meclisin istemi üzerine, toplantı dönemi başlamadan önce toplantı dönemi süresince serbest bırakılırlar. Japonya'da yasama dokunulmazlığına ilişkin diğer hususlar Diet Kanununun 33'üncü maddesinde düzenlenmiştir. Buna göre, yasama dokunulmazlığı sadece cezaî alanda geçerlidir (http://www.ipu.org/parline-e/ reports/2161.htm, 1.5.2001). Bütün suçlan kapsar. Ancak Parlâmento üyesini sadece tutuklanmaya (arrest) ve gözaltına almaya (preventive custody) karşı korur. Parlâmento üyesine karşı kovuşturma açılabilir. Keza parlâmento üyesinin evinde arama da yapılabilir (lbid.). Yasama dokunulmazlığı suçüstü (flagrante

2827 Aralık 1947 tarihli Italyan Anayasasının Italyanca metni için bkz: http://www. palazzochigi.it/ sez_costituzione.html (1.2.2001). Ingilizce çevirisi için bkz.: http://www.uni-wuerzburg.de/law/it00000_.html (1.2.2001).

$29 \mathrm{La}$ legge cost. 29 ottobre 1993, n. 3 (G.U. 30 ottobre 1993, n. 256). (http://www.palazzochigi.it/ sez_costituzione/note.html, 1.2.2001).

3017 Haziran 1944 tarihli lzlanda Anayasasının Ingilizce çeviri metni için bkz.: http://www. richmond.edu/ - jpjones/confinder/Iceland2.htm (1.2.2001).

313 Kasım 1946 tarihli Japon Anayasasının Ingilizce çeviri metni için bkz.: http://www.uni-wuerzburg.de/ law/ja00000_html (1.2.2001). 
delicto) hâlinde işlemez (Diet Kanunu [Diet Law], m.33; http://www.ipu.org/ parline-e/reports/2161.htm, 1.5.2001). Yasama dokunulmazlığ 1 Parlâmento üyesinin tanık sıfatyyla mahkemeye çağrilmasın da engeller (Medenî Usôl Kanunu, m.144; Ceza Usûl Kanunu, m.144; http://www.ipu.org/parline-e/ reports/2161.htm, 1.5.2001). Yasama dokunulmazlığ1 Japonya'da sadece parlâmentonun toplantı dönemleri (sessions) boyunca koruma sağlar (http://www.ipu.org/parline-e/reports/2161.htm, 1.5.2001). Dolayısıyla diğer dönemlerde parlâmento üyeleri tutuklanabilir. Yasama dokunulmazliğ1 Parlâmento tarafından kaldırılabilir. Parlâmento üyesi dinlenmez. Keza Parlâmento kaldırma kararına karşı itiraz hakkı yoktur (Ibid.). Japonya'da Parlâmento kendi tutuklanmış üyelerinin tutukluluk halini askıya alma (suspension of the detention) yetkisi vardir (1946 Japon Anayasas1, m.50; Diet Kanunu, m.34; http://www.ipu.org/parline-e/reports/2161.htm, 1.5.2001). Keza, tutuklanmış veya hapsedilmiş milletvekilinin Parlâmento toplantılarına katılmasina izin verilebilir (http://www.ipu.org/parline-e/reports/2161.htm, 1.5.2001).

19. Kanada.- 1867-1982 Kanada Anayasasının ${ }^{32}$ 18'inci maddesine göre Parlâmento üyelerinin sahip olacakları imtiyaz ve dokunulmazlıklar Parlâmentonun çıkaracağı bir kanunla belirlenecektir. Bununla birlikte Anayasa bu kanunun getirebileceği imtiyaz ve dokunulmazlıkları şu şekilde sinırlandırmaktadır. Imtiyaz ve dokunulmazlikları belirleyen kanun, bu Anayasanın kabul edilmesi sırasında Birleşik Krallıkta Avam Kamarasının sahip olduğu imtiyaz ve dokunulmazliklardan daha fazla imtiyaz ve dokunulmazlık tanuyamayacaktır. Kanada'da yasama dokunulmazlığı Kanada Parlâmentosu Hakkında Kanunun 4'üncü maddesi tarafından düzenlenmiştir (Loi sur le Parlement du Canada, http://www.ipu.org/parline-f/reports/1055.htm, 1.5.2001). Bu Kanuna göre, Kanada'da yasama dokunulmazlığı vardır; Parlâmento üyesi tutuklanamaz, gözaltına alınamaz; ancak bu dokunulmazlık sadece hukukî (civile) alanda geçerlidir (http://www.ipu.org/ parline-f/reports/1055.htm, 1.5.2001). Yani parlâmento üyeleri suçlarından dolayı tutuklanabilir ve yargılanabilirler. Kanada'da yasama dokunulmazlığı parlâmento üyelerinin tanık sıfatıyla mahkemeye çağrılmasına da engeldir (Ibid.). Ancak hatırlatalım ki, bu dokunulmazlık sadece medenî sahada geçerlidir (Ibid.). Yasama dokunulmazlığı toplantı dönemini ve başlangıcından 40 gün önce ve bitişinden 40 gün sonrasını kapsar (Ibid.). Yasama dokunulmazlığı kaldırlabilir niteliktedir. Bu konuda karar yetkisi Avam Kamarasına aittir. Bu konuda milletvekili dinlenmelidir. Milletvekili Avam Kamarasının önünde itiraz hakkına sahiptir (lbid.).

32 Kanada Anayasas1 1867 tarihli British North America Act ve 1982 tarihli Constitution Act'an oluşmaktadur (http://www.georgetown.edu/ LatAmerPolitical/Constitutions/ Canada/ canada1867.html) 
20. Lüksemburg.- 1868 Lüksemburg Anayasasınin ${ }^{33} 69^{\prime}$ uncu maddesine göre, ağır bir suçu işlerken yakalanmadıkça, hiçbir milletvekili, Meclisin izni olmaksızın, toplantı dönemi boyunca cezaî bir konuda soruşturulamaz ve tutuklanamaz. Keza milletvekilleri toplant dönemi boyunca ayn izin olmaksızın borçlarından dolayı hapsedilemezler. Bir milletvekilinin tutukluluğu veya soruşturulması Meclis talep ederse toplantı dönemi boyunca askıya alınur. Yasama dokunulmazlığ 1 sadece Parlâmentonun toplantı dönemi boyunca işler (http://www.ipu.org/parline-f/reports/1191.htm, 1.5.2001). Yasama dokunulmazlığı kaldırılması usûlünde parlâmento üyesi de özel bir komisyon tarafından dinlenir (Ibid.). Dokunulmazlığın kaldırılması kararına karşı milletvekili başvuru itiraz hakkına sahip değildir (Ibid.).

21. Norveç.- 1814 Norveç Anayasasının ${ }^{34} 66^{\prime} \mathrm{ncl}$ maddesine göre, milletvekilleri, bir suçu alenî olarak işlerken yakalanmadikça (unless they are apprehended in public crimes), yani suçüstü hâli hariç, Storting'e gidiş ve dönüş yollarında ve Storting'te bulunduklan sürece tutuklanmaktan muaftırlar. Norveç'te yasama dokunulmazlığı hem hukukî, hem de cezaî sahada geçerlidir (http://www.ipu.org/parline-f/reports/1239.htm, 1.5.2001). Milletvekilleri mahkemelere tank olarak çağrlabilir (Ibid.). Yasama dokunulmazlığı milletvekillerini görevlerinin başlangıcından sonuna kadar korumaktadır (Ibid.). Norveç'te yasama dokunulmazlığ kaldırılamaz (lbid.). Hapis ve gözaltına alma durumunda milletvekilinin parlâmento toplantılarına katılmasına izin verilebilir (Ibid.).

22. Portekiz.- 1976 Portekiz Anayasasının ${ }^{35} 160^{\prime \prime n c ı ~ m a d d e s i n i n ~ i k i n c i ~}$ fıkrasına göre, milletvekilleri Meclisin izni olmaksızın tutuklanamaz ve gözaltına alınamaz. Aynı fıkraya göre suçüstü hâli bu hükümden hariçtir. Bununla birlikte, milletvekilinin suçüstü halinde işlediği suç en az üç yıl hapis cezasıyla cezalandırılabilir nitelikte olmalıdır. Bunun dışındaki durumlarda, milletvekiline karşı bir ceza soruşturması açıldığında, Meclis soruşturmanın devam edip etmeyeceğine karar verir (m.160/3). 1976 Portekiz Anayasasına göre ayrıca milletvekilleri, Meclisin toplantı döneminde, Meclisin izni olmaksızın, jüri üyesi, bilirkişi ve tanık olarak mahkemelere çağrılamazlar (m.161/1). Yasama dokunulmazlığı milletvekilinin seçilmesinden görevinin sona ermesine kadar devam eder (http://www.ipu.org/parline-f/reports/ 1257.htm, 1.5.2001). Anayasanun 157'nci maddesine göre, yasama

3317 Ekim 1868 tarihli Lüksemburg Anayasasının Fransızca ash için bkz.: http://www.etat.lu/SCL/ CNST0999.PDF (10.3.2001); Ingilizce çeviri metni için bkz.: http://www.uni-wuerzburg.de/law/lu_ indx.html (1.2.2001).

3417 Mayıs 1814 tarihli Norvę Anayasasının lngilizce çeviri metni için bkz.: http://odin.dep.no/ odin/ engelsk/ norway/ system/032005-990424/ index-dok000-b-n-a.html (1.2.2001).

352 Nisan 1976 tarihli Portekiz Anayasasının Ingilizce çevirisi için bkz.: http://www. parlamento.pt/ constit/ crp_ing.html (1.2.2001). 
dokunulmazlığının Parlâmento tarafından kaldırılması sürecinde milletvekili dinlenir. Bununla birlikte milletvekili dokunulmazlığın kaldırılması kararına karşı başvuru hakkına sahip değildir (Ibid.).

23. Türkiye.- 1982 Türk Anayasasının 83'üncü maddesinin ikinci fikrasina göre, "seçimden önce veya sonra bir suç işlediği ileri sürülen milletvekili, Meclisin kararı olmadıkça tutulamaz, sorguya çekilemez, tutuklanamaz ve yargılanamaz. Ağır cezayı gerektiren suçüstü hâli ve seçimden önce soruşturmasına başlanılmış olmak kaydıyla Anayasanın 14 üncü maddesindeki durumlar bu hükmün dışındadır. Ancak, bu halde yetkili makam, durumu hemen ve doğrudan doğruya Türkiye Büyük Millet Meclisine bildirmek zorundadır". Yine aynı maddeye göre "Türkiye Büyük Millet Meclisi üyesi hakkında, seçimden önce veya sonra verilmiş bir ceza hükmünün yerine getirilmesi, üyelik sıfatınn sona ermesine bırakılır; üyelik süresince zamanaşımını işlemez" (m.83/3). "Tekrar seçilen milletvekili hakkında soruşturma ve kovuşturma, Meclisin yeniden dokunulmazlığın kaldırmasına bağlıdır (m.83/4). "Türkiye Büyük Millet Meclisindeki siyasî parti gruplarınca, yasama dokunulmazlığı ile ilgili görüşme yapılamaz ve karar alınamaz" (m.83/4).

24. Yeni Zelanda.- 1986 Yeni Zelanda Anayasasında ${ }^{36}$ yasama dokunulmazlığına ilişkin bir hüküm bulunmamaktadır. Inter-Parliamentary Union'un web sayfasında Yeni Zelanda'da yasama dokunulmazlığ kavramunun mevcut olmadığını belirtilmektedir (http://www.ipu.org/parline-e/reports/ 2233.htm, 1.5.2001).

25. Yunanistan.- 1975 Yunan Anayasasının ${ }^{37} 62$ 'nci maddesine göre, yasama dönemi boyunca, hị̧̧ir milletvekili, Parlâmentonun izni olmaksızın soruşturulamaz, tutuklanamaz, hapsedilemez veya hürriyeti bir başka şekilde kısitlanamaz. Savcı tarafından Parlâmento Başkanından istenmesinden itibaren üç ay içinde izin konusunda karar verilmemiş ise, bu iznin verildiği varsayllır. Üç aylık süre Parlâmentonun çalışmalarına ara verdiği sürelerde işlemez. Suçüstü hâlinde izne gerek yoktur (m.62). Keza Yunan Anayasasl, diğer anayasalardan farklı olarak eski milletvekillerine yönelik ilginç ve istisnaî bir dokunulmazlık getirmiştir. Anayasa göre, feshedilmiş Parlâmentonun üyeleri de, bu Parlâmentonun feshinden yeni Parlâmentonun seçilmesine kadar geçecek sürede siyasal suçlarından (political crimes) dolayı soruşturulamazlar (m.62). Parlâmento üyeleri tanık sufatıyla mahkemelere çağrılabilir (http:// www.ipu.org/parline-e/reports/2125.htm, 1.5.2001). Yasama dokunulmazlğ

361 Ocak 1986 tarihli Yeni Zelanda Anayasasının Ingilizce metni için bkz: http://www.uni-wuerzburg.de/law/nz02000_html

379 Haziran 1975 tarihli Yunan Anayasasının Ingilizce çeviri metni için bkz: http://www.uni-wuerzburg.de/law/gro000_html (1.2.2001). 
parlâmento üyeliğinin başlangıcından sonuna kadar devam eder (Ibid.). Gözaltına alınmış veya hapsedilmiş parlâmento üyelerinin Parlâmento toplantılarına katılmasına izin verilebilir (Ibid.).

\section{KARŞILAŞTIRMALI GÖZLEMLER}

Incelediğimiz 25 ülkenin 23'ünde yasama dokunulmazlı̆̆ kurumu mevcuttur. Yasama dokunulmazlığı kurumu sadece 1983 Hollanda Anayasası ve 1986 Yeni Zelanda Anayasası tarafından kabul edilmemiştir.

\section{A. YASAMA DOKUNULMAZLIĞININ GEÇERLİL̇K ALANI}

Yasama dokunulmazlığının geçerli olduğu alan bakımından ülkeler üç gruba ayrilabilir.

1. Yasama Dokunulmazlığının Sadece Cezaî Alanda Geçerli Olduğu Ülkeler.- Yasama dokunulmazlığının mevcut olduğu yirmi üç ülkeden on dördünde yasama dokunulmazliğı sadece cezâ̂ alanda (en matière pénale) geçerlidir. Bu ülkelerde yasama dokunulmazlı̆̆ parlâmento üyelerini sadece cezâ̂ takiplere (criminal proceedings) karşı korur. Bu ülkeler Almanya, Avusturya, Belçika, Finlandiya, Fransa, Ispanya, İsveç, İsviçre, Italya, İzlanda, Japonya, Portekiz, Türkiye ve Yunanistan'dır. Japonya dışında bu ülkeler Avrupa'da bulunmaktadır. Bu ülkelerin hepsi kıta Avrupası hukuk sistemine sahiptir. Bu ülkelerin hepsinde kamu hukuku-özel hukuk ayrımı vardır. Bu ülkelerde özel hukuk kapsamındaki eylem ve işlemlerinden dolayı parlâmento üyelerine taninmı̧ bir dokunulmazlık yoktur. Bu ülkelerde borcunu ödemeyen milletvekiline karşı dava açılabilir; bu milletvekili hakkında bütün hukukî takipler (civil proceedings) yaplabilir. Keza suç teşkil eden bir fiil ile başkasına zarar veren parlâmento üyesi hakkında suçtan zarar gören kişi, haksız fiil hükümlerine dayanarak Parlâmento üyesine karşı hukuk davası açıp, ondan tazminat isteyebilir. Keza milletvekili hakkında cebrî icra yoluna da gidilebilir.

2. Yasama Dokunulmazlığının Sadece Hukukî Alanda Geçerli Olduğu Ülkeler.- Yasama dokunulmazlığınn mevcut olduğu yirmi üç ülkenin beşinde yasama dokunulmazlığı sadece hukukî alanda (en matière civile) geçerlidir. Yani bu ülkelerde yasama dokunulmazlığı parlâmento üyelerini cezaî takiplere (criminal proceedings) karşı değil, sadece hukukî takiplere (civil proceedings) karşı korur. Bu ülkeler Amerika Birleşik Devletleri, Avustralya, Ingiltere, İrlanda ve Kanada'dır. Bu ülkelerin hepsi Anglo-Sakson hukuk sistemine mensup ülkelerdir. Yani bu ülkelerde parlâmento üyeleri özel hukuk alanındaki borçlarından dolayı tutuklanamayacaklardır. Bununla birlikte bu ülkelerde parlâmento üyelerinin işledikleri (ceza hukuku anlamında) suçlardan dolayı tutuklanmaları, yarglanmaları ve hapsedilmeleri mümkündür. 
3. Yasama Dokunulmazlığının Hukukî+Cezaî Alanda Geçerli Olduğu Ülkeler.- Yasama dokunulmazlığının mevcut olduğu yirmi üç ülkenin dördünde yasama dokunulmazlığı hem cezấ, hem de hukukî alanda (en matière pénale et civile) geçerlidir. Yani bu ülkelerde yasama dokunulmazlığı parlâmento üyelerini hem cezâ, hem de hukuks alanda bazı işlemlere karşı korumaktadır. Bu ülkeler Danimarka, Israil, Lüksemburg ve Norveç'tir.

\section{B. YASAMA DOKUNULMAZLIĞININ GEÇERLIULK SÜRESI}

Parlâmento üyelerinin yasama dokunulmazlığından yararlandığı süre bakımından incelediğimiz ülkeler iki gruba ayrılmaktadır.

1. Yasama Dokunulmazlığının Parlâmento Üyeliğinin Başından Sonuna Kadar Geçerli Olduğu Ülkeler.- Yasama dokunulmazlığının mevcut olduğu yirmi üç ülkenin on üçünde yasama dokunulmazlığından parlâmento üyeleri, görevlerinin başlamasından sona ermesine kadar yararlanurlar. Bu ülkeler Almanya, Avusturya, Danimarka, Finlandiya, Fransa, İspanya, Israil, İsveç, Italya, Norveç, Portekiz, Türkiye ve Yunanistan'dır.

2. Yasama Dokunulmazlığının Parlâmentonun Toplantı Dönemleri Boyunca Geçerli Olduğu Ülkeler.- Yasama dokunulmazlığının mevcut olduğu yirmi üç ülkenin onunda yasama dokunulmazlığ bütün yasama dönemi boyunca değil, parlâmentonun toplantı dönemleri (sessions) süresince işler. Bu şu anlama gelir ki, parlâmentonun toplantı dönemleri arasinda parlâmento üyeleri yasama dokunulmazlığından yararlanmaz. Bu zamanlarda parlâmento üyeleri tutuklanabilirler. Bu ülkeler, Amerika Birleşik Devletleri, Avustralya, Belçika, Ingiltere, Irlanda, Isviçre, Izlanda, Japonya, Kanada ve Lüksemburg'tur.

\section{YASAMA DOKUNULMAZLIĞININ ISTISNALARI}

Yasama dokunulmazlığının istisnaları bakımından incelediğimiz ülkeler iki gruba ayrilmaktadır.

1. İstisnasız Tanıyanlar.- Amerika Birleşik Devletleri, Avustralya, Ingiltere, Irlanda ve Kanada'da yasama dokunulmazlığının istisnaları yoktur. Bu ülkelerde yasama dokunulmazlığı kapsamındaki istisnasız bütün fiiller yasama dokunulmazlığından yararlanırlar. Ancak hatırlatalım ki, bu ülkelerde yasama dokunulmazliğı sadece hukukî alanda tanınmıştır; parlâmento üyelerine hukukî takiplere (civil proceedings) karşı korumaktadır. Dolayısıyla parlâmento üyelerinin zaten suç teşkil eden fiilleri bakımından kendilerine tanunmıs herhangi bir dokunulmazlık yoktur.

2. İstisnalı Tanıyanlar.- Yasama dokunulmazlı̆ın cezaî alanda tanıan ülkelerin hepsinde (Almanya, Avusturya, Belçika, Danimarka, Finlandiya, 
Fransa, Ispanya, Isveç, Isviçre, Israil, Italya, Izlanda, Japonya, Lüksemburg, Norveç, Portekiz, Türkiye ve Yunanistan) yasama dokunulmazlığının bazı istisnaları.i.yasama dokunulmazlyğynyn istisnalary; (derogations, dérogations) vardır. Bu istisnalar şunlardır:

a) Suçüstü Hâli.- Bu istisnalardan birincisi ve en yaygın suçüstü (cürm-ü meşhut, flagrante delicto, flagrant délit) hâlidir. Almanya, Avusturya, Belçika, Danimarka, Fransa, İspanya, İsveç, Isviçre, Israil, İtalya, Izlanda, Japonya, Lüksemburg, Norveç, Portekiz, Türkiye ve Yunanistan'da suçüstü hâli yasama dokunulmazlığının istisnası durumundadır. Yani bu ülkelerde bir parlâmento üyesi bir suçu işlerken yakalanmış ise, yasama dokunulmazlığından yararlanmaz. Parlâmento üyesi bu durumda tutuklanabilir ve yargılanabilir. Bazı ülkelerde suçüstü hâlinde yakalanan parlâmento üyesinin işlediği suçun belirli bir ağırlıkta olması gerekmektedir. Örneğin 1868 Lüksemburg Anayasası, suçüstü hâli işlenen suçun ağır suç (serious offense) niteliğinde olmasını aramaktadır (m.69). 1976 Portekiz Anayasası ise parlâmento üyesinin suçüstü hâlinde işlediği suçun en az üç yl hapis cezasıyla cezalandırılabilir nitelikte olmasını şart koşmaktadır (m.160/2). 1982 Türk Anayasası ise suçüstü hâlinde işlenen suçun ağır cezalık olmasın şart koşmaktadır (m.83).

b) Belirli Ağırlıktaki Suçlar.- Bazı ülkelerde ise belirli bir miktardan fazla hapis cezası gerektiren bir suçun işlenmesi durumunda yasama dokunulmazlığı işlememektedir. Örneğin 1999 Finlandiya Anayasasına göre, Parlâmento üyesi en az altı aydan fazla hapis cezası gerektiren bir suçu işlediğine ilişkin esaslı sebepler varsa yasama dokunulmazlığından yararlanamaz (sek.30). 1975 Isveç Anayasasına göre işlenen suçun minimum cezasının iki yıl hapisten fazla olması durumunda Parlâmento üyesi yasama dokunulmazlı̆gndan yararlanamaz (b.3, $\mathrm{m} .8 / 2$ ).

c) Kaçma Şüphesi.- İsviçre'de kaçma şüphesi altında bulunan parlâmento üyesi tutuklanabilmektedir (Loi fédérale sur les garanties politiques et de police en faveur de la Confédération, m.1/2 http://www.ipu.org/parline-f/reports/ 1303.htm, 1.5.2001).

d) Itiraf.- 1975 İsveç Anayasasına göre ise parlâmento üyesi suçunu itiraf ettiği durumlarda yasama dokunulmazlı̆g işlememektedir (b.3, m.8). Yasama dokunulmazlığının amacı yürütme organı tarafından tahrik edilebilecek düzmece suç soruşturmalarıyla parlâmento üyelerini rahatsız etmemek olduğuna göre, parlâmento üyesinin kendisinin de suçunu kabul etmesi durumunda, burada düzmece değil, ciddî bir suç soruşturması olduğu ortaya çımış olur.

e) Kesin Hükümle Mahkûmiyet.- 1958 Fransız Anayasasina (m.26/2) ve 1947 İtalyan Anayasasına (m.68) göre, kesin hükümle mahkûmiyet hâlinde yasama dokunulmazlığı işlemez. Parlâmento üyesi hapse konulabilir. Yasama 
dokunulmazhı̆ının amacı düzmece suç soruşturmalarından parlâmento üyelerini korumaktır. Kesin hükümle mahkûmiyet hâlinde burada parlâmento üyesinin suçluluğunun kesin olarak ortaya çıkmış olur. Bu durumda parlâmento üyesi yasama dokunulmazlığından yararlanamamasının yasama dokunulmazl1ğının amacı ile uzlaşmaz nitelikte olmayacaktır.

f) Adî Suçlar.- Yasama dokunulmazlığına en geniş istisna 1929 Avusturya Anayasası tarafından getirilmiştir. Bu Anayasanın 57'nci maddesinin üçüncü fıkrası göre, Millî Meclis üyelerinin işlediği suç "üyenin siyasî faaliyetleriyle açıkça bağlantısız (manifestly not connected to the political activity of the member)" ise üye hakkında cezaî takip yapılabilmesi için yasama dokunulmazlığının kaldırılmasına gerek yoktur. Yani Avusturya'da Meclis üyelerinin adî suçlarından dolayı kural olarak bir dokunulmazlıkları yoktur. Ancak, söz konusu üye veya bu konularla görevli Meclisin Daimî Komite üyelerinin üçte biri talep ederse, ilgili makam, Millî Meclisten, üyeye atfettiği suçun onun siyasî faaliyetleriyle bağlantisız bulunduğu konusunda bir karar almak zorundadır. Böyle bir talep olduğunda, soruşturma sürecindeki bütün işlemler o aşamada durur (m.57/3). Millî Meclis bu talep konusunda sekiz hafta içinde karar vermemiş ise, gerekli izni verdiği varsayılır (m.57/4).

\section{YASAMA DOKUNULMAZLIĞININ SAĞLADIĞI GÜVENCELER}

Yasama dokunulmazlığı parlâmento üyesine bütün adlî takiplerden bağışı tutma gibi bir güvence sağlamaz. Yasama dokunulmazlığı parlâmento üyesine sınırlı sayıda güvence sağlar. Bu güvenceleri her ülke için aynı kavramlarla tasnif etmek güç olsa da biz bunları beş gruba ayırdık.

1. Gözaltına Alınmaya Karşı Güvence.- 1953 Danimarka Anayasası (sek.57), 1999 Finlandiya Anayasası (sek.30), 1978 Ispanyol Anayasası (m.71), 12 Şubat 1958 tarihli Knesset Hakkında İsrail Temel Kanunu (sek.17), 1975 İsveç Anayasası (b.3, m.8), 1999 İsviçre Anayasası (m.162), 1947 Italyan Anayasası (m.68), 1944 Izlanda Anayasası (m.48), 1946 Japon Anayasası (m.50), 1868 Lüksemburg Anayasası (m.69), 1814 Norveç Anayasası (m.66), 1976 Portekiz Anayasası (m.160), 1982 Türk Anayasası (m.83) ve 1975 Yunan Anayasasına (m.61) göre yasama dokunulmazlığı parlâmento üyclerini gözaltına (preventive custody, détention préventive) alınmaya karşı korumaktadır.

2. Tutuklamaya Karşı Güvence.- Yasama dokunulmazhğını kabul eden bütün ülkelerin anayasaları, parlâmento üyelerini tutuklanmaya (arrest, arrestation) karşı korumaktadır. Yasama dokunulmazlığının bütün ülkelerdeki ortak anlaminın tutuklanmama güvencesi olduğunu söyleyebiliriz.

3. Kovuşturma Açılmasına Karşı Güvence.- Incelediğimiz ülkelerin onunda anayasalar parlâmento üyelerine karşı parlâmentonun izni olmadan 
kovuşturma açılmasını (openning of judicial proceedings, ouverture de poursuites juridiques) yasaklamaktadırlar. Bu anayasalar şunlardır: 1953 Danimarka Anayasası (sek.57), 1978 Ispanyol Anayasası (m.71), 12 Şubat 1958 tarihli Knesset Hakkında Israil Temel Kanunu (sek.17), 1999 Isviçre Anayasası (m.162). 1944 tzlanda Anayasası (m.48), 1868 Lüksemburg Anayasası (m.69), 1976 Portekiz Anayasası (m.160) ve 1975 Yunan Anayasası (m.61).

4. Aramaya Karşı Güvence.- 1949 Alman Anayasası (m.46/2), 1929 Avusturya Anayasası (m.57/2), 1994 Belçika Anayasası (m.59), 12 Şubat 1958 tarihli Knesset Hakkında Israil Temel Kanunu (sek.17), 1999 Isviçre Anayasası (m.162) ve 1947 Italyan Anayasasına (m.68) göre yasama dokunulmazlı̆̆ parlâmento üyelerinin evlerinin aranmasına (house searche, perquisition domiciliaire) karşı da güvence sağlar. Bu ülkelerde parlâmento üyelerinin evlerinin aranabilmesi için de parlâmentonun izni gerekir.

5. Tanık Olarak Çağrnlmaya Karşı Güvence.- İncelediğimiz ülkelerin çoğunluğunda yasama dokunulmazlığı parlâmento üyesi mahkemelere tanık sifatıyla çağrılmasına (being called as witnesses, citation à comparaitre en qualité de témoin) engel değildir. Bununla birlikte, Avustralya (sek.49), Japonya (m.50) ve Portekiz'de (m.160) parlâmento üyeleri mahkemelere tank sifatiyla da çağrılamazlar. Ingiltere'de ise Avam Kamarası üyeleri kural olarak mahkemelere tanık olarak çağrılabilir. Ancak Speakers üyenin Avam Kamarası toplantısına katılması gerektiğini bildirirse, Avam Kamarası üyesi tanık olarak da çağrılamaz (http://www.ipu.org/parline-e/reports/2335.htm, 1.5.2001). Almanya'da ise Bundestag üyeleri tanık sıfatıyla mahkemelere çağrılabilir. Bununla birlikte Bundestag üyeleri toplantı döneminde Bundestag'in olduğu bulunduğu yerde dinlenilmelidirler (Ceza Usûl Kanunu, m.50/1; Medenî Usâl Kanunu, m.382/2; http://www.ipu.org/parline-f/reports/1121.htm, 1.5.2001).

6. Hürriyetten Mahrum Edici Her Türlü Tedbire Karşı Güvence.- 1958 Fransız Anayasası (m.26/2) yasama dokunulmazlığının nelere karşı güvence sağladığın tek tek belirtmemiş, onun yerine hürriyetten mahrum edici veya hürriyeti sınurlayıcı bütün diğer tedbirler (toute autre mesure privative ou restrictive de libertê) ifadesini kullanmıştır. Şüphesiz bu ifade, tutmayı, gözaltına almayı, tutuklamayı ve hapsi içeren bir ifadedir.

7. Dinlenmeye Karşı Güvence.- 1947 Italyan Anayasası (m.68) Parlâmento üyelerinin konuşmalarının veya haberleşmelerinin dinlenebilmesi ile mektuplarına veya yazışmalarına el konulabilmesine (intercettazione di conversazioni o comunicazioni e a sequestro di corrispondenza) karşı da güvence getirmektedir. 


\section{E. YASAMA DOKUNULMAZLIĞININ KALDIRILMASI}

Yasama dokunulmazlığı her şeye karşı güvence getirmediği gibi getirdiği güvenceler de mutlak değildir. Parlâmentonun yasama dokunulmazlığın kaldırması durumunda bu güvenceler işlemez. Yasama dokunulmazlığının kaldırılması (leave of parliamentary inviobility, levée de l'inviobilité parlementaire) bakımından incelediğimiz ülkeler bu açıdan iki gruba ayrılabilir:

1. Yasama Dokunulmazlığınun Kaldırılamadığı Ülkeler.- Amerika Birleşik Devletleri, Avustralya, Ingiltere, Irlanda, Isvę̧ ve Norveç'te yasama dokunulmazlığı kaldırılamaz. Ancak Amerika Birleşik Devletleri, Avustralya, Ingiltere ve Irlanda'da zaten yukarıda açıkladığımız gibi yasama dokunulmazliğı sadece hukukî alanda vardır. Parlâmento üyelerini sadece hukukî takiplere (civil proceedings) karşı korur. O nedenle, bu dokunulmazlığın kaldırılamaz nitelikte olmasınun bir sakıncası yoktur. Isveç'te ise yasama dokunulmazlığı parlâmento üyesinin suçlarına karşı koruma sağlamasına rağmen, bu ülkede de yasama dokunulmazlığının kaldırılmasının mümkün olmamasının büyük bir sakıncası yoktur. Zira bir kere, parlâmento üyesi suçüstü hâlinde yakalanması durumunda ve keza suçunu itiraf etmesi durumunda yasama dokunulmazlığı işlemez. Asıl önemlisi Isveç'te iki yıldan fazla hapis cezası gerektiren suçlar yasama dokunulmazlığının kapsamı dışındadırlar. Norveç'te ise yasama dokunulmazlığından sadece suçüstü hâli istisna olmakla birlikte, bu ülkede parlâmento üyelerinin tutuklanmamak ve gözaltına alınmamak şartıyla kovuşturulması mümkündür.

2. Yasama Dokunulmazlığının Kaldırılabildiği Ülkeler.- Almanya, Avusturya, Belçika, Danimarka, Finlandiya, Fransa, Ispanya, Isviçre, Israil, Italya, İlanda, Japonya, Lüksemburg, Portekiz, Türkiye ve Yunanistan'da yasama dokunulmazlığı kaldırılabilmektedir.

a) Kaldırma Yetkisi.- Kaldırma yetkisi genellikle tek meclisli parlâmentolar da bu parlâmentoya, iki meclisli parlâmentolar da ise yasama dokunulmazlığ kaldırılacak olan parlâmento üyesinin ait olduğu meclise aittir. Bununla birlikte, Almanya'da kaldırma yetkisi Bundestag'a veya Seçimleri Denetleme, Bağışılık ve İçtüzük Komisyonuna aittir. Fransa'da ise yasama dokunulmazlığı kaldırılması yetkisi Parlâmentonun kendisine değil, dokunulmazlığı kaldırılacak olan Parlâmento üyesinin ait olduğu Meclisin Başkanlık Divanına (Bureau de l'Assemblée) aittir. Isviçre'de ise Parlâmento üyesinin kendisi de kendi dokunulmazlığının kaldırılmasına izin verme yetkisine sahiptir.

b) Yeter Sayı.- Yasama dokunulmazlığı kaldırılması için genellikle anayasalar özel bir karar yetersayısı öngörmemektedirler. Yani parlâmentolar adî çoğunluğuyla bir üyenin yasama dokunulmazlığını kaldırabilirler. Bununla birlikte, incelediğimiz ülkelerin birisinde yasama dokunulmazlığının 
kaldırılması karan için nitelikli çoğunluk öngörülmektedir. Finlandiya'da yasama dokunulmazlığı kaldırılması karanı ancak Parlâmentoda kullanılan oyların altıda beşiyle alınabilir (sek.30/2).

c) Karar Süresi.- Genellikle yasama dokunulmazlığı kaldırılması için anayasalar bir süre öngörmemektedir. O nedenle parlâmentonun kendisinden istenen yasama dokunulmazlığı kaldırılması konusunu hemen görüşmeyip ihmal etmesi mümkündür. Ancak incelediğimiz ülkelerin birinde bunu engellemek için maksimum süre öngörülmüştür. 1975 Yunan Anayasasına göre sava tarafından Parlâmento Başkanından istenmesinden itibaren üç ay içinde bu konuda karar verilmemiş ise, yasama dokunulmazlığının kalkhğı varsayllır (m.62).

d) Parlâmento Üyesinin Savunmast.- Yasama dokunulmazlığının kaldırılması usâlünde bazı ülkelerde parlâmento üyesine söz verilir; diğer bazı ülkelerde ise söz verilmez. Almanya, Belçika, Danimarka ve Japonya'da parlâmento üyesi dinlenmez; buna karşılık Ispanya, Israil, Isviçre, Italya, Kanada, Lüksemburg, Portekiz, Türkiye, Yunanistan'da dinlenir.

e) Parlâmento Üyesinin Ittiraz Hakkt.- Sadece üç ülkede parlâmento üyesi dokunulmazlığının kaldınıması karanna karşı başvuruda bulunma hakkı (right of appeal, droit de recours) vardır. Almanya'da dokunulmazlığ kaldırılan Bundestag üyesi bu karara karşı Federal Anayasa Mahkemesine başvurabilir. Isviçre'de de dokunulmazlığı kaldırılan Parlâmento üyesinin itiraz hakkı vardır. Türkiye'de yasama dokunulmazlığ 1 kaldırılan milletvekili bu karara karşı Anayasa Mahkemesine başvurabilir (m.85).

\section{F. TUTKULULUĞUN VEYA KOVUŞTURMANIN ASKIYA ALINMASI}

Almanya, Avusturya, Belçika, Fransa ve Japonya'da yasama dokunulmazlığının dışında Parlâmentoların tutuklanmış üyelerinin tutukluluğunu askıya alma (suspension of the detention, suspension de l'arrestation) veya üyeleri hakkında yapılan kovuşturmayı askıya alma (suspension of the prosecution, suspension des poursuites) yetkisine sahiptir. Belçika'daki sistem ilginçtir. 1994 Belçika Anayasasına göre Belçika'da Parlâmento üyelerinin Istinaf Mahkemesi Başkanunun kararıyla tutuklanabilmesi mümkündür (m.59/2). Keza Belçika'da parlâmento üyelerinin dokunulmazlıklarının kaldırılmadan haklarında kovuşturma açılması da mümkündür (m.59/4). Bununla birlikte Parlâmento üyesinin istemesi durumunda, ait olduğu Meclis, kovuşturmanın askıya alınmasına karar verebilir (m.59/5). Il gili Meclis bu konudaki kararın kullanılan oyların üçte iki çoğunluğuyla alabilir (m.59/5). Keza, Meclis, üyesinin tutukluluğu veya bir mahkeme tarafından yargılanması askıya alınmasına da karar verebilir (m.59/son). 


\section{G. Sonuç: iki sistem}

Yukarıda yaptığımız karşılaştırmaya göre incelediğimiz ülkelerdeki düzenlemelere bakarak yasama dokunulmazlığı bakımından iki sistemin mevcut olduğunu söyleyebiliriz.

1. Anglo-Sakson Sistemi.- Birincisi Amerika Birleşik Devletleri, Avustralya, Ingiltere, Irlanda ve Kanada'nun içinde yer aldığı Anglo-Sakson sistemidir. Bu sistemde yasama dokunulmazlığı cezaî alanda değil, sadece hukukî alanda geçerlidir; yani parlâmento üyelerine sadece borçlarından dolayı tutuklanmama güvencesi sağlar. Bu sistemde, geçerli olduğu alanda (yani hukukî alanda) yasama dokunulmazlığının istisnaları yoktur. Keza bu ülkelerde - yasama dokunulmazliğ Bununla birlikte bu sistemde yasama dokunulmazlığı cezaî alanda geçerli olmadığı için parlâmento üyelerine önemli bir güvence sağlamaz; parlâmento üyeleri, diğer vatandaşlar gibi suçlarından dolayı tutuklanabilir ve yargılanabilir. Kaldı ki, hukukî sorumluluk alanında tutuklama tedbirine ve hapis müeyyidesine günümüzde başvurulmamaktadır. Borçlarından dolayı sadece parlâmento üyeleri değil, kimse tutuklanmamaktadır. Bu nedenle Anglo-Sakson sisteminde yasama dokunulmazlığının günümüzde pek bir anlamının kalmadığın söyleyebiliriz.

2. Kıta Avrupası Sistemi.- Ikinci sistem Almanya, Avusturya, Belçika, Danimarka, Finlandiya, Fransa, Ispanya, İsrail, Isveç, İsviçre, Italya, İzlanda, Japonya, Lüksemburg, Norveç, Portekiz, Türkiye ve Yunanistan'da uygulanmaktadır. Bu sisteme "kıta Avrupası sistemi" ismini verebiliriz. Bu sistemde, yasama dokunulmazlığı esas itibarıyla hukukî alanda değil ${ }^{38}$, sadece cezaî alanda geçerlidir. Yani parlâmento üyeleri suçlanından dolayı tutuklanamasa ve yargılanamasa bile onlara karşı hukuk davası açlip tazminat istenebilir. Bu sistemde yasama dokunulmazlığınn istisnaları vardır. Genellikle suçüstü hâlinde işlenmiş suçlar yasama dokunulmazlığının kapsamında bulunmaz. Diğer yandan yasama dokunulmazlığı parlâmento tarafından kaldırılabilir niteliktedir. Nihayet, yasama dokunulmazlığı kaldırılmamıs olsa bile mutlak bir koruma sağlamaz. Genellikle gözaltına alınmama, tutuklanmama gibi güvenceler sağlar. Ülkelerin çoğunluğunda parlâmento üyesi hakkında hürriyetten mahrum edici tedbirler uygulanmadıkça soruşturma açlabilir; bazı ülkelerde parlâmento üyesi hakkında dava açılabilir; parlâmento üyesi tanık olarak dinlenebilir.

Ulaşığımız sonuçlar özet olarak aşağıdaki tabloda gösterilmiştir. 
TABLO : YIRYI BEŞ ULKEDE YASAMA DOKUNULMAZLIGI

\begin{tabular}{|c|c|c|c|c|c|c|c|c|c|c|c|c|c|}
\hline Ülke & AY & Madde & Süre & Alan & Ístisnalar & $\begin{array}{c}\text { 1Gö } \\
\text { zatı }\end{array}$ & $\begin{array}{c}\text { 2.Tut } \\
\text { ukla }\end{array}$ & $\begin{array}{c}\text { 3.Kov } \\
\text { uştu }\end{array}$ & $\begin{array}{l}\text { 4.Ar } \\
\text { ama }\end{array}$ & $\begin{array}{r}5 . \mathrm{Ta} \\
\text { nık }\end{array}$ & $\begin{array}{l}\text { 6.Tal } \\
\text { dirm }\end{array}$ & \begin{tabular}{|l} 
7.Bas \\
vur
\end{tabular} & $\begin{array}{c}\text { 8.As } \\
\text { kı }\end{array}$ \\
\hline 1. A.B.D. & 1787 & m.1.b.6 & Toplantı Dönemi & Hukukî & Yok & & + & & & - & - & & \\
\hline 2. Almanya & 1949 & $\mathrm{~m} .46 / 2$ & Baştan Sona & Cezaî & Suçüstü Hâli & & + & & + & - & + & + & + \\
\hline 3. Avustralya & 1900 & sek.49 & Toplantı Dönemi & Hukukî & Yok & & + & & & + & - & & \\
\hline 4. Avusturya & 1929 & $\mathrm{~m} .57 / 2$ & Baştan Sona & Cezaî & Suçüstü Hâli & & + & & + & - & + & & + \\
\hline 5. Belçika & 1994 & m.59 & Toplantı Dönemi & Cezaî & Suçüstü Hâli & & + & + & + & - & + & - & + \\
\hline 6. Danimarka & 1953 & sek. 57 & Baştan Sona & Hukukî+Cezaî & Suçüstü Hâli & + & + & - & - & - & + & $=$ & \\
\hline 7. Finlandiya & 1999 & sek.30 & Baştan Sona & Cezaî & 6 Ay Hapis Cezası+Esaslı Sebepler & + & + & & & & + & & \\
\hline 8. Fransa & 1958 & $\mathrm{~m} .26 / 2$ & Baştan Sona & Cezaî & Suçüstü+Mahkumiyet & + & + & - & - & - & + & - & + \\
\hline 9. Hollanda & 1983 & YOK & & & & & & & & & & & \\
\hline 10. Ingiltere & & & Toplantı Dönemi & Hukukî & Yok & & & & & + & - & & \\
\hline 11. Irlanda & 1937 & b. $15 / 13$ & Toplantı Dönemi & Hukukî & Yok & & + & & & & - & & \\
\hline 12. Ispanya & 1978 & 71 & Baştan Sona & Cezaî & Suçüstü Hâli & + & + & + & - & - & + & - & - \\
\hline 13. Israil & 1958 & sek.17 & Baştan Sona & Hukukî̀+Cezaî & Suçüstü Hâli & + & + & + & + & - & + & - & - \\
\hline 14. Isveç & 1975 & b.3,m.8 & Bastan Sona & Cezaî & Suçüstü, 2 Y 1 l Hapis Cezası, Itiraf & + & + & & & & - & & - \\
\hline 15. Isviçre & 1999 & $\mathrm{~m} .162$ & Toplantı Dönemi & Cezaî & Suçüstü Hâli, Kaçma Şüphesi & + & + & & & + & + & + & \\
\hline 16. Italya & 1947 & m.68 & Baştan Sona & Cezaî & Suçüstü+Kesin Hüküm & + & + & & + & - & + & & \\
\hline 17. Izlanda & 1944 & $\mathrm{~m} .48$ & Toplantı Dönemi & Cezaî & Suçüstü Hâli & + & + & + & & & + & & \\
\hline 18. Japonya & 1946 & $\mathrm{~m} .50$ & Toplantı Dönemi & Cezaî & Suçüstü Hâli & + & + & - & - & + & + & - & + \\
\hline 19. Kanada & 1867 & $\mathrm{~m} .18$ & Toplantı Dönemi & Hukukî & Yok & & + & & & & + & + & \\
\hline 20. Lüksemburg & 1868 & m.69 & Toplantı Dönemi & Hukukî̀+Cezaî & Ağır Suçüstü Hâli & + & + & + & & - & + & - & - \\
\hline 21. Norveç & 1814 & $\mathrm{~m} .66$ & Baştan Sona & Hukukî̀+Cezầ & Suçüstü Hâli & + & + & & & & - & & \\
\hline 22. Portekiz & 1976 & $\mathrm{~m} .160$ & Baştan Sona & Cezaî & Suçüstü Hâl+3 Yıl Hap. Cezası & + & + & + & & + & + & - & \\
\hline 23. Türkiye & 1982 & $\mathrm{~m} .83 / 2$ & Baștan Sona & Cezâi & Ağır Cezalık Suçüstü, m. 14'teki & + & + & & & - & + & + & - \\
\hline 24. Yeni Zelanda & 1986 & YOK & & & & & & & & & & & \\
\hline 25. Yunanistan & 1975 & $\mathrm{~m} .61$ & Baştan Sona 1 & Cezaî & Suçüstü Hâli & + & + & + & & - & + & & \\
\hline
\end{tabular}

1. Gözaltına (preoentize custody, détention pretentioe) karşı koruma

2. Tutuklamaya (arrest, arrestation) karşı koyma

3. Kovuşturmaya açılmasına (openning of judicial proceedings; ouderture de poursuites juridiques) karşı koruma

4. Aramaya (house searche, perquisition domiciliaire) karşı koruma

5. Tanı olarak çağnılmaya (being called as witnesses, citation a comparaitre en qualite de témoin) karşı koruma

6. Yasama dokunulmazlığının kaldınlması (leote de l'inviobilite parlementaire, leave of parliamentary inviobility)

7. Kaldırma kararina karşı basvuru (appeal, appel, recours) hakkı

8. Parlamentonun tutuklamayı veya soruşturmayı askya alma (suspension of the detention, the prosecution, suspension de l'arrestation, des poursuites) yetkisi 


\section{Kaynaklar}

\section{Kitaplar}

ARDANT, Philippe (1996), Institutions politiques et droit constitutionnel (Paris: L.G.D.J., Sekizince Bask1).

ARSEL, Ihan (1965), Türk Anayasa Hukukunun Umumi Esaslan (Ankara: Mars Matbaası).

AUTEXIER, Christian (1997), Introduction au droit public allemand (Paris: PUF).

BARTHÉLEMY, Joseph / DUEZ, Paul (1933), Traité de droil constitutionnel (Paris: Dalloz).

CHAGNOULAUD, Dominique (1999), Droit constitutionnel contemporain (Paris: Editions Sirey).

DE SMTH, S.A. / BRAZIER, Rodney (1989), Constitutional and Administrative Law (London: Penguin Books, Altuncı Baski).

DÖNMEZER, Sulhj / ERMAN Sahir (1985), Nazari ve Tabiki Ceza Hukuku (lstanbul: Filiz Kitabevi, Dokuzuncu Baskı) (Cilt I).

FAVOREU, Louis et al. (1998), Droit constitutionnel (Paris: Dalloz).

GICQUEL, Jean (1999), Droit constitutionnel et institutions politiques (Paris: Montchrestien, Onaluncı Baskı). GÖZLER, Kemal (2000), Türk Anayasa Hukuku (Bursa: Ekin Kitabevi Yayınları).

GREWE, Constance / RUIZ FABRI, Hélène (1995), Droits constitutionnels européennes (Paris: PUF).

HOOD PHILUPS, O. / JACKSON, Paul (1987), Constitutional and Administrative Law (London: Sweet E Maxwell, Yedincl Baskı).

LAFERRIÉRE, Julien (1947), Manuel de droit constitutionnel (Paris: Editions Domat-Montchrestien, Ikinci Baskı).

LAVROFF, Dmitri Georges (1995), Le droit constitutionnel de la Ve République (Paris: Dalloz).

UJPHART, Arend (Tarihsiz), Cağdaş Demokrasiler (Ankara: Yetkin Yayınları) (Çev.: Ergun Özbudun ve Ersin Onulduran).

NOWAK, John E. / ROTUNDA, Ronald D. / YOUNG, J. Nelson (1978), Handbook on Constitutional Law (St. Paul, Minn.: West Publishing Co.)

ÖZBUDUN, Ergun (2000), Türk Anayasa Hukuku (Ankara: Yetkin Yayınları, Altıncı Baskı).

PACTET, Pierre (1994), Institutions politiques-Droit constitutionnel (Paris: Masson, Onüçũncũ Baskı).

TRIBE, Laurence H. (2000), American Constitulional Law (New York: Foundation Press), Cilt l.

VEDEL, Georges (1949), Droit constitutionnel (Paris: Sirey).

WILSON, James Q. / DIIUUO, John J. (1995), American Covemment: Institutions and Politics (Lexington: D.C. Heath and Company, Altincı Baskı).

\section{Anayasalar}

A.B.D.: 17 Eylü] 1787 Tarihll Amerika Birleşik Devletleri Federal Anayasası (Ingilizce Aslı): http://www.constitution. org/ constit_.htm (1.2.2001).

Almanya: 23 Mayis 1949 Tarihli Alman Anayasası (Ingilizce Cevirisi): http://www.uni-wuerzburg.de/law/ gm00000_html (1.2.2001).

Avustralya: 1900 Tarihli Avustralya Anayasasının Ingillzce metni Için bkz.: http://www.uni-wuerzburg. de/law/as00000_html (1.2.2001).

Avusturya: 1929 Avusturya Anayasası (Bundes-Verfassungsgeselz in der Fassung von 1929) (Ingilizce Cevirisi): http://www.uni-wuerburg.de/ law/as00000_html (1.2.2001). 
Belçika: 17 Subat 1994 Tarihll Belçika Anayasası (Fransizca Aslı): http://www.senate.be/ senbeldocs/ constitution/ const_fr.html (1.2.2001); Inglizce Cevirisi: http://www.uni-wuerzburg.de/law/ be00000_.html. (1.2.2001).

Danlmarka: 5 Haziran 1953 Tarihli Danimarka Anayasası: hup://www.unj-wuerzburg.de/ law/ da00000_html (1.2.2001).

FInlandlya: 11 Haziran 1999 Tarihli Finlandiya Anayasası (Ingilizce Cevirlsi): http://www.om.fl/ constitution/ 3340.htm (1.2.2001).

Fransa: 4 Ekim 1958 Tarihll Fransız Anayasası (Fransizca Aslı): http://www.leglfrance. gouv.fr/ html/frame_ constitution.htm (1.2.2001). Ingllizce Cevirlsi: http://www.assemblee-natlonale.fr/ 8/8ab.htm (1.2.2001).

Hollanda: 17 Şubat 1983 Tarihli Hollanda Anayasası (Ingilizce Cevirisi): http://www.uni-wuerzburg.de/ law/nl00000_.html (1.2.2001).

Irlanda: 1 Temmuz 1937 Tarihli Irlanda Anayasası (Ingilizce Aslı): http://www.math.tcd.je/pub/ Constitution.html (1.2.2001).

Ispanya: 27 Aralık 1978 Tarihli Ispanyol Anayasası (Ingilizce Cevirisi): http://www.uni-wuerzburg.de/law/ sp00000_html (1.2.2001). Ispanyoica Asls: http://www.igsap.map.es/docs/cia/dispo/ constitu.htm

Israll: 16 Haziran 1964 Tarihli Devlet Başkan Hakkında Israil Temel Kanunu (Basic Law: The President of the State) (Ingilizce Cevirisi): http://www.uni-wuerzburg.de/ law/is_indx.html (1.2.2001).

Isveç: 1 Ocak 1975 Tarihli Isvę Anayasası (Ingilizce Cevirisi): http://www.uni-wuerzburg.de/law/ sw00000_html (1.2.2001).

Isviçre: 14 Nisan 1999 Tarihli Isviçre Anayasası (Fransızca Aslı): http:/www.admin.ch/ ch/f/rs/101/ index.html (1.2.2001); Ingilizce Cevirisl: http:/www.uni-wuerzburg.de/ law/sz00000_.html (1.2.2001).

Italya: 27 Aralık 1947 Tarihll Italyan Anayasası (Italyanca Aslı): http://www.palazzochigi.It/ sez_ costituzione.html (1.2.2001); Ingllizce Cevirisl: http://www.uni-wuerzburg.de/ law/it00000_html (1.2.2001).

Izlanda: 17 Haziran 1944 Tarihli Izlanda Anayasas (Ingilizce Cevirisi): http://www. richmond.edu/ Jpjones/confinder/ Iceland2.htm (1.2.2001).

Japonya: 3 Kasım 1946 Tarihli Japon Anayasası (Ingilizce Cevirisi): http://www.uni-wuerzburg.de/ law/ja00000_html (1.2.2001).

Japonya: 1867 tarihli British North America Act ve 1982 tarihll Constitution Act'an oluşan Kanada Anayasası (Ingilizce Ash): (http://www.georgetown.edu/ LatAmerPolitical/Constitutions/ Canada/ canada 1867.html (1.2.2001)

Luksemburg: 17 Ekim 1868 Tarihlı Lüksemburg Anayasası (Fransızca Aslı) http://www.etat.lu/ SCL/CNST0999.PDF (10.3.2001); (Ingilizce Cevirisi): http://www.uni-wuerburg.de/law/lu_ Indx.html (1.2.2001).

Norveç: 17 Mayıs 1814 Tarihli Norveç Anayasası (Ingilizce Cevirisi): http://odin.dep.no/ odin/ engelsk/ norway/ system/032005-990424/ index-dok000-b-n-a.html (1.2.2001).

PortekJz: 2 Nisan 1976 Tarihli Portekiz Anayasası (Ingilizce Cevirisi): http://www. parlamento.pt/ constit/crp_Ing.html (1.2.2001). Portekizce Aslı: http://www.cea. ucp.pt/lei/const/constind.htm (1.2.2001).

Turklye: 7 Kasım 1982 Tarihli Türkjye Cumhuriyeti Anayasası: Resmi Gazete, 9.11.1982, Sayı 17863 Mükerrer, Düstur, Beşlnci Tertip. Clit 22, s.3.

Yenl Zelanda: 1 Ocak 1986 Tarihli Yenl Zelanda Anayasası (Ingilizce Metri): http://www.unl-wuerbburg.de/ law/nz02000_html (1.2.2001) 
Yunanlstan; 9 Haziran 1975 Tarihll Yunan Anayasası (Ingilizce Cevirisi): http://www. hri.org/MFA/ syntagma/artcl50.html (1.2.2001); http://www.uni-wuerzburg-de/law/gr0000_html (1.2.2001).

Dünya ũlkelerinin anayasa metinlerinin Ingilizce çevirilerine șu lkl siteden ulaşlabilir:

"ICL: International Constitutlonal Law", http://www.uni-wuerzburg.de/law/ (Bu site A. Tschentscher tarafından yönetilmektedir).

"Constltution Finder", http://www.richmond.edu/ Jjjones/confinder/const/html (Bu site Richmond Universitesi profesörlerinden John Paul Jones tarafından yönetilmektedir).

\section{Inter-Parliamentary Union, Parline Database'da Ülke Raporlarmın Adresleri}

ABD: http://www.lpu.org/parline-f/reports/1339.htm (1.5.2001).

Almanya: http://www.lpu.org/parline-f/reports/1121.htm (1.5.2001).

Avustralya: http://www.jpu.org/parline-f/reports/1015.htm (1.5.2001).

Avusturya: http://www.ipu.org/parline-f/reports/1017.htm (1.5.2001).

Belçlka: http://www.ipu.org/parline-f/reports/1029.htm (1.5.2001).

Danlmarka: http://www.ipu.org/parline-e/reports/2087.htm (1.5.2001).

Finlandlya: http://www.ipu.org/parline-f/reports/1111.htm (1.5.2001).

Fransa: http://www.ipu.org/parline-f/reports/1113.htm (1.5.2001).

Hollanda: http://www.ipu.org/parline-e/reports/2231.htm (1.5.2001).

Ingiltere: http://www.jpu.org/parline-e/reports/2335.htm (1'.5.2001).

Irlanda: http://www.jpu.org/parline-e/reports/2153.htm (1.5.2001).

Ispanya: http://www.jpu.org/parline.f/reports/1293.htm (1.5.2001).

lsrall: http://www.ipu.org/parline-f/reports/1155.htm (1.5.2001).

Isveç: http://www.ipu.org/parline-f/reports/1303.htm (1.5.2001).

Isvlçre: http://www.jpu.org/parline-f/reports/1305.htm (1.5.2001).

Italya: http://www.ipu.org/parline-e/reports/2157.htrn (1.5.2001).

Izlanda: http://www.jpu.org/parline-e/reports/2173.htm (1.5.2001).

Japonya: http://www.jpu.org/parline-e/reports/2161.htm (1.5.2001).

Kanada: http://www.jpu.org/parline-f/reports/1055.htm (1.5.2001).

Luksemburg: http://www.ipu.org/parline-f/reports/1191.htm (1.5.2001).

Norveç: http://www.jpu.org/parline-f/reports/1239.htm (1.5.2001).

Porteklz: http://www.jpu.org/parline-f/reports/1257.htm (1.5.2001).

Türklye: http://www.jpu.org/parline-f/reports/1323.htm (1.5.2001).

Yenl Zelanda: http://www.ipu.org/parline-e/reports/2233.htm (1.5.2001).

Yunanlstan: http://www.lpu.org/parline-e/reports/2125.htm (1.5.2001). 


\section{IV. Ülke Parlâmentoların Web Siteleri}

ABD: http://www.house.gov ; http://www.congress.gov

Almanya: http://www.bundestag.de

Avustralya: http://www.aph.gov.au/house/

Avusturya: http://www.parlinkom.gv.at

Belçlka: http://www.fed-parl.be ; http://www.dekamer.be/

Danlmarka: http://www.folketinget.dk ; http://www.ft.dk

Flnlandlya: http://www.eduskunta.fi

Fransa: http://www.assemblee-nationale.fr

Hollanda: http://www.dds.nl/overheld/pdc/; http://www.parlement.nl

IngIltere: http://www.parliamentuk

Irlanda: http://www.Irlgov.ie/oireachtas/

Ispanya: http://www.congreso.es

Israll: http://www.knesset.gov.jl ; http://www.Israel-mfa.gov.jl/gov/knesset.html

Isveç: http://www.riksdagen.se/

Isvlçre: http://www.parllament.ch

Italya: http://www.parlamento.it; http://www.camera.jt/

Japonya: http://www.shugiin.go.jp

Kanada: http://www.parl.gc.ca

Luksemburg: http://www.chd.lu

Norveç: http://sauce.uio.no/Stortinget/; http://www.stortinget.no

PortekJz: http://www.parlamento.pt

Turklye: http://www.tbmm.gov.tr

Yenl Zelanda: http://www.parliament.govt.nz

Yunanistan: http://www.parliament.gr 